Article

\title{
Taxonomy, Distribution and Evolution of Trisopterine Gadidae by Means of Otoliths and Other Characteristics
}

\author{
Pieter A. M. Gaemers \\ Joost van den Vondelstraat 30, 7103 XW Winterswijk, The Netherlands; pamgae143@gmail.com; \\ Tel.: +31-543-750383 \\ Academic Editor: Eric Hallerman \\ Received: 1 April 2016; Accepted: 7 July 2016; Published: 17 July 2017
}

\begin{abstract}
In a greater study of the recent fossil Gadidae, the object of this paper is to better define the trisopterine species and their relationships. The taxonomy of the four recent species usually included in the genus Trisopterus is further elaborated by means of published and new data on their otoliths, by published data on general external features and meristics of the fishes, and their genetics. Fossil otoliths, from the beginning of the Oligocene up to the present, reveal much of their evolution and throw more light on their relationships. Several succeeding and partly overlapping lineages representing different genera are recognized during this time interval. The genus Neocolliolus Gaemers, 1976, for Trisopterus esmarkii (Nilsson, 1855), is more firmly based. A new genus, Allotrisopterus, is introduced for Trisopterus minutus (Linnaeus, 1758). The similarity with Trisopterus capelanus (Lacepède, 1800) is an example of convergent evolution. The tribe Trisopterini Endo (2002) should only contain Trisopterus, Allotrisopterus and Neocolliolus as recent genera. Correct identification of otoliths from fisheries research and from sea bottom samples extends the knowledge of the present day geographical distribution of T. capelanus and T. luscus (Linnaeus, 1758). T. capelanus is also living along the Atlantic coast of Portugal and at least up to and including the Ría de Arosa, Galicia, Spain. There it can easily be mistaken for A. minutus that is also living there. Otoliths of T. luscus have been identified from the Evvoïkós Channel between Euboia and the mainland of Greece, thus it must live also in the Aegean Sea. Otoliths prove to be a powerful tool in taxonomy, biogeography and evolution of teleosts.
\end{abstract}

Keywords: Trisopterus; Neocolliolus; new genus Allotrisopterus; Trisopterini; new data on systematics; evolution; and biogeography

\section{Introduction}

From Linnaeus onwards the cod family Gadidae included a large and often variable cluster of different gadiform fishes (see for instance [1-6]). Progressive insight of many researchers has rightly curtailed the number of species that should be included in this family. In the literature, this group is usually ranked as the subfamily Gadinae (see [2-8]). Following Howes [9] and Fahay [10], I define the Gadidae family here as comprising only the species with three dorsal fins. Twelve genera are usually distinguished among the living representatives of this family, comprising 22 recent species. Raniceps raninus (Linnaeus, 1758), a primitive gadiform species with two dorsal fins of which the first is tiny and the second very long, should not be included in the Gadidae as indicated by Eschmeyer [11], but should be placed in the separate family Ranicipitidae, erected by T.P. Gill [12], see [8].

The Gadidae live in cold to temperate seas, where there is much less food available in the winter. Therefore, the cods are generalists, opportunistic feeding on a large variety of prey species. Closely related species are often too much competitors of one another because of a similar position in the 
food web. This explains the poor cladogenesis in this family: five genera, Arctogadus, Boreogadus, Melanogrammus, Merlangius and Theragra are monotypic (see revision of Arctogadus in Jordan et al. [13] and of Theragra in Byrkjedal et al. [14] (Theragra finnmarchica Koefoed, 1956 is supposed to be synonymous with Theragra chalcogramma (Pallas, 1811), see [10]); five genera, Eleginus, Gadiculus, Microgadus, Micromesistius and Pollachius, comprise two species, the genus Gadus comprises three species (but never more than two in the same area), and the genus Trisopterus, as it is usually defined up to now, comprises four species, of which often three are living in the same area (in this study it will be shown that Trisopterus capelanus (Lacepède, 1800) is a separate species and not a subspecies). For the following four genera it is certain that at present never more than one species of the genus occurs in an area, because of geographic separation: Eleginus, Gadiculus, Microgadus, and Micromesistius. It should be noted that Gadiculus argenteus Guichenot, 1850 and Gadiculus thori Schmidt, 1913, are not subspecies as it has been assumed since Svetovidov [2,15,16], but are actually two different species based on otolith morphology and ontogeny, larval pigmentation and external features of adults (see also Schmidt [17]). Trisopterus thus seems to be an exception, with a more extensive cladogenesis and more species living together in the same area than any other gadid.

The taxonomy and evolution of the trisopterine Gadidae have been the subject of several specific studies since the beginning of the 21st century, stimulated by new genetic data within this group [18-22], and by new genetic data of a larger group of Gadiformes including some trisopterine species $[7,8]$. The profound investigations by Delling et al. [21] moreover are indispensable because they have straightened up the taxonomic mess in the trisopterines that started already in the beginning of scientific taxonomy before Linnaeus and continued up to their publication. In a wise manner they designated neotypes for $A$. minutus and T. capelanus, and a lectotype for T. luscus, as well as neotypes for several synonyms of these species.

The aim of the present study is to further update the taxonomy and evolution of the trisopterine Gadidae based on recent and fossil otoliths, with the inclusion of other data from the literature. Evidence will be given that cladogenesis in trisopterine Gadidae is not more extensive than in other gadids. With the genera Neocolliolus and Allotrisopterus included, the number of genera in the Gadidae amounts to fourteen.

In order to clearly distinguish between recent and fossil taxa a dagger $(\dagger)$ is placed before a genus or species that is extinct.

\section{Results, Including a Survey of Characteristics of Recent Trisopterines}

\subsection{Factors Influencing Otolith Shape}

1. Shape changes during ontogeny. It is important to shortly describe the changes that occur in otoliths during ontogeny. Otoliths usually start to grow before hatching as a tiny sphere. In the larval stage, at first, length increases more rapidly than the other dimensions. Thereafter, the height of the otolith increases more rapidly than thickness. Therefore, a more specific shape starts forming. Soon also a beginning of ornamentation develops. The number of knobs and furrows increases during early growth and also the relief becomes more pronounced. Usually in the late youth or early adulthood of the fish the relief is highest and the number of knobs stops augmenting. When becoming older the relief flattens more and more. In the course of growth the relative width and depth of the sulcus also increase in Gadidae and other families. Finally, the length-height and length-thickness ratios of otoliths are not only changing in the beginning of the life of the fish, but remain in a state of change during the whole life of the fish. In the first part of the life of a fish, otoliths become more slender and thinner. Some species show this tendency in their otoliths during their whole life, but many show a reversal trend in later life, when otoliths gradually become higher and thicker again [3]. These allometrical developments can be weak or strong, depending on the species and/or the phylogenetic stage. If this allometry is strong, it is possible that early and late ontogenetic stages of the same species are wrongly interpreted as different species. 
2. In any species, there is variability among its individuals. Otoliths are no exception in this respect. Shape differences in otoliths may be the result of genetic differences, but also environmental factors may influence otolith shape. Sometimes aberrant shapes occur and occasionally the left and right otolith are remarkably different. It is not yet known what causes such phenomena.

3. Within an evolutionary lineage of a gadid species the shape of the otoliths gradually change according to a fixed pattern that probably is genetically controlled [3]. Every lineage suddenly starts without a gradual change, originating from an older lineage that usually has a big overlap in geological time with the younger lineage. The otoliths of the new lineage have many characteristics in common with the old lineage, but the new lineage also shows some new features, so that they usually can be distinguished easily by an experienced otolith specialist. In its first phylogenetic stage the otoliths are relatively short and thick, becoming more slender and thinner in its second stage. In the third stage, the otoliths are most slender and thin; afterwards, they become again shorter and thicker in the last, fourth, stage. Every gadid species evolves in this way and there is no fifth stage, so every species becomes extinct at a certain moment in time. The otoliths of many gadid species gradually evolve from smaller to larger in the course of hundreds of thousands or millions of years [3], but there is now much evidence that the otoliths of still a considerable number of species evolve to smaller sizes. Rarely the size of gadid otoliths remains the same during the whole evolution of the species. It is logical to suppose that the size of the fishes in an evolutionary lineage changes in the same direction as the otoliths do. However, complete fossil gadid fish skeletons are rare, thus this assumption usually cannot be proven by fossils.

4. Sexual dimorphism can occur in otoliths. This phenomenon was discovered for the first time in recent small cichlid species from Lake Victoria, Tanzania. It occurs only in species that have large size differences between males and females [23]. Individuals of the larger sex do not only get larger otoliths, but also get more slender otoliths with more ornamentation. Later it was also found in several extinct Gadidae species, which have (much) smaller otoliths than those of Gadiculus argenteus Guichenot 1850, the smallest cod species living today [24]. It is logical to assume that the maximum size of these extinct species was (distinctly) smaller than $15 \mathrm{~cm}$, the maximum total length of G. argenteus. The smallest fossil Gadidae species probably did not become larger than $5 \mathrm{~cm}$.

Recent gadid females grow always larger and become older than males, and there is no reason to suppose that this was different for extinct species and genera in this family. Therefore the larger, more slender and ornamented otoliths within a population of otoliths of a fossil gadid are considered to be female otoliths. Why larger gadid species with size difference between the sexes do not-or only slightly-show sexual dimorphism in their otoliths, is not known.

5. There is also evidence that temperature may have some influence on the shape of otoliths. Near the northern (coldest) or southern (warmest) limits in several cases the otoliths of a species have different OL/OH and OL/OT ratios (OL: otolith length in $\mathrm{mm} ; \mathrm{OH}$ : otolith height (width) in $\mathrm{mm}$; OT: otolith thickness in $\mathrm{mm}$ ). In the coldest areas otoliths may be more slender and thinner, in the warmest areas they may be shorter (higher) and thicker. Examples of more slender and thinner otoliths are those of Limanda limanda (Linnaeus, 1758) [25]: Plate 91, figures A-F, in Härkönen (1986) compared to those from the same species in the southern North Sea. The same applies to the otoliths of Microstomus kitt (Walbaum,1792) [25]: Plate 93, figures C-F, compared to Plate 93, figures A,B; the latter figures represent higher otolith shapes that are known from the southern North Sea. The same may be true for the more slender otoliths of Phrynorhombus norvegicus (Günther, 1862) [25]: see Plate 88, figures C-F, Trachinus draco (Linnaeus, 1758) [25]: see Plate 72, figures A-D, and Taurulus bubalis (Euphrasen, 1786) [25]: Plate 50, figures A-F, compared to more southern otoliths in my own collection of recent otoliths. Furthermore, I observed that otoliths of Micromesistius poutassou (Risso, 1826) from the Mediterranean are higher than those in the Atlantic, and also the otoliths of Merlangius merlangus (Linnaeus, 1758) from the Adriatic Sea are higher than those in the Atlantic. I never found the reverse situation, that the otoliths of a certain species in warmer areas are more slender, so it seems 
to be a rule, that if the otolith shape changes under different temperature conditions, the change is consistently always in the same direction.

From the above-mentioned factors it is clear that one needs to study a large amount of otoliths in order to have a complete overview of the sizes and shapes of the otoliths of a (sub)species, and so ensuring good identification of closely related (sub)species. If this is done for one or a few (sub)species, it is not necessary to do it equally extensively for all (sub)species because overall variability can then be estimated also for other related (sub)species.

It is very important to picture otoliths of closely related species at the same magnifications in order to be able to notice differences between species and different phylogenetic stages of species at a given size of the otoliths. Otherwise the changes in shape during ontogeny and phylogeny often cannot be appreciated in the correct way, and can easily lead to misidentifications. Unfortunately, different otolith taxonomists use different magnifications and some taxonomists even use various magnifications in one publication. This hinders easy comparison. I would highly recommend to use standard magnifications (for instance $5 \times, 10 \times, 15 \times, 20 \times$ ), depending on the maximum size of the otoliths of a species.

\subsection{Characteristics of Gadidae Otoliths}

In order to understand the taxonomic importance of otoliths, firstly it is necessary to describe and illustrate different primary characteristics of the external morphology of Gadidae otoliths (Figure 1). When using the term otolith, always the sagitta is meant, which is the largest otolith or ear stone in most bony fish families. The most important element of an otolith, functionally as well as taxonomically, is the sulcus acusticus or hearing groove, where numerous offshoots of the hearing nerve end. The sulcus acusticus, also shortly named sulcus, is situated on the inner (medial) surface of the otolith. The sulcus runs lengthwise on the otoliths, parallel to the length of the whole fish. The sulcus can be divided in two or three different portions. The anterior portion is called the ostium, the posterior portion is the cauda. In between, a collum can be present or absent. In the Gadidae the outline of the sulcus is always homosulcoid: ostium and cauda are clearly distinguishable and have about the same shape, so that the sulcus is more or less symmetrical [26]; the type of sulcus opening in the Gadidae usually is pseudobiostial: the sulcus ends indistinctly very near to the anterior and posterior margins, so that both ostium and cauda are closed toward the margins; sometimes the sulcus opening in the Gadidae is biostial: both ostium and cauda are open at the margins [26]. Ostium and cauda are usually filled partly or nearly entirely with cushions, called ostial respectively caudal colliculum. The colliculi do not extend to the margins. In otoliths of some Gadidae species a pseudocolliculum (a narrow ridge) occurs at the ventral part of the collum. Nolf and Steurbaut [27] use the term central collicular crest for it. The sulcus is often surrounded by narrow ledges or kinks, the crista superior and the crista inferior. The outline of this surface shows a broad anterior part in Gadidae otoliths, called the rostral margin, and a more or less pointed posterior end. Various angular portions may occur along the outline. In Gadidae otoliths pre- and postdorsal angles are usually present. Furthermore, ornamentation of lower or higher rounded knobs may occur along the margins. On the reverse side, the outer surface, usually rounded knobs occur, separated by sharp furrows. The ventral portion of a Gadidae otolith is usually thicker than the dorsal portion; sometimes ventral and dorsal portions are equally thick. The ventral and dorsal views show the thickness of the otolith and if the otolith is flat or bent lengthwise; they also show details of the curvature of the inner and outer surfaces. 


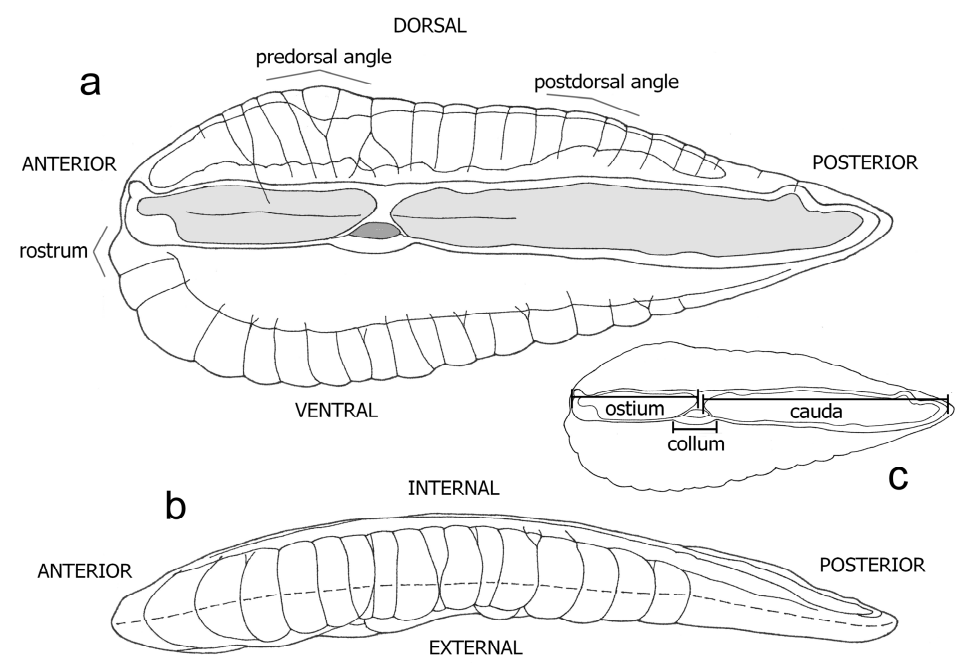

Figure 1. Left otolith of + Colliolus mistensis Gaemers, 1990. (a) Inner surface showing length and height (or width) of the otolith; the colliculi are light grey, the medially situated pseudocolliculum is dark grey; the ventral margin is regularly bent, the dorsal margin has a distinct predorsal angle and a weak postdorsal angle; (b) Ventral view showing length, thickness and lengthwise curvature of the otolith;

(c) Overview with ostium, cauda and collum.

\subsection{Otolith Characteristics of Recent Trisopterine Gadidae}

Recent trisopterine otoliths can easily be distinguished from otoliths of other gadids:

- Pear shaped (also in Gadiculus-like and extinct Colliolus-like otoliths)

- Thick, especially the adult otoliths

- Sulcus (very) wide

- Colliculi long and wide, largely filling sulcus and touching one another

- Collum only at ventral part of sulcus

- Pseudocolliculum absent

\subsection{Other Characteristics of Trisopterine Gadidae}

A synopsis of several biological characteristics of trisopterine Gadidae summarized from the literature is given in Tables 1 and 2. Trisopterine fishes are small gadids, most of which usually do not become larger than $25 \mathrm{~cm}$ in total length, whereas their maximum size rarely exceeds $30 \mathrm{~cm}$; only Trisopterus luscus (Linnaeus, 1758) normally can grow up to $46 \mathrm{~cm}$ (Table 1). Their life span is short, generally between 3 and 5 years, and they mature mostly in their second year (Table 1). Otoliths, of course, become larger when the fishes grow, but the largest fishes do not necessarily have the largest otoliths (compare fish size and otolith size in Table 1). This is caused by a greater variability in the OL/TL ratio in larger fish (OL: otolith length in mm; TL: total fish length in mm).

Trisopterines inhabit the continental shelf and the upper part of the continental slope. The smallest and youngest fishes live in the shallowest waters; adult fishes can live in the deepest waters of their depth range (Table 2). Apart from young individuals, Neocolliolus esmarkii (Nilsson, 1855) lives in the deepest waters, usually in the lower part of the continental shelf.

All trisopterines are schooling to a lesser or greater extent (Table 2). Due to their relatively small size they are rather low in the food web and are common to abundant in European seas. This is also valid for the Tertiary and Quaternary, the more so as otoliths of ancestral lineages are known to grow to smaller maximum sizes than recent ones. Thus, fossil species must have remained smaller than the recent representatives. Trisopterine otoliths are common in marine sediments of northwestern Europe from the Oligocene up to the present day, so that it is well possible to reconstruct their phylogeny. 
Table 1. Synopsis of ages and sizes of recent trisopterine Gadidae.

\begin{tabular}{|c|c|c|c|c|c|c|c|c|}
\hline Species & $\begin{array}{c}\text { Age of Females } \\
\text { When } 50 \% \\
\text { Are Mature }\end{array}$ & $\begin{array}{c}\text { Age of Males } \\
\text { When } 50 \% \\
\text { Are Mature }\end{array}$ & $\begin{array}{l}\text { Maximum Known } \\
\text { Age (Normal } \\
\text { Max. Age) }\end{array}$ & $\begin{array}{l}\text { TL of Females } \\
\text { When } 50 \% \text { Are } \\
\text { Mature (in mm) }\end{array}$ & $\begin{array}{c}\text { TL of Males } \\
\text { When } 50 \% \text { Are } \\
\text { Mature (in mm) }\end{array}$ & $\begin{array}{l}\text { Normal } \\
\text { Maximum TL } \\
\text { (in mm) }\end{array}$ & $\begin{array}{c}\text { Extreme } \\
\text { Maximum TL } \\
\text { (in } \mathrm{mm})\end{array}$ & $\begin{array}{l}\text { Maximum } \\
\text { Observed OL } \\
{\text { (in } \mathrm{mm})^{\mathrm{a}}}^{\mathrm{a}}\end{array}$ \\
\hline Neocolliolus esmarkii & 1.5 years $^{b}$ & 1.2 years $^{b}$ & $7^{\mathrm{c}}\left(3^{\mathrm{d}}-4^{\mathrm{e}}\right)$ & $140^{\mathrm{e}}$ & $150^{\mathrm{e}}$ & 235 & $350^{\mathrm{f}}$ & 9.07 (TL $205 \mathrm{~mm})$ \\
\hline Allotrisopterus minutus & 1.7 years $\mathrm{g}$ & 2.7 years $\mathrm{g}$ & $7^{\mathrm{g}}(4-5)$ & $160-190^{\mathrm{h}}$ & $140-200^{\mathrm{h}}$ & 245 & $280^{g}$ & 11.68 (TL $269 \mathrm{~mm}$ ) \\
\hline Trisopterus luscus & 1.7 years $^{i}$ & 1.8 years $^{i}$ & $9^{j}(5)$ & $\begin{array}{c}220^{\mathrm{i}, \mathrm{k}} \\
192^{\mathrm{k}}\end{array}$ & $234^{\mathrm{i}}$ & $460^{j}$ & $490^{1}$ & 14.55 (TL $415 \mathrm{~mm}$ ) \\
\hline Trisopterus capelanus & end 1 st year ${ }^{m}$ & end 1 st year ${ }^{m}$ & $6^{\mathrm{m}, \mathrm{n}}(4)$ & $\begin{array}{c}133^{\circ} \\
138.2^{\mathrm{p}}\end{array}$ & $\begin{array}{c}125^{\circ} \\
123.9^{\mathrm{p}}\end{array}$ & $250^{n}$ & $320^{q}$ & 12.82 (TL $288 \mathrm{~mm}$ ) \\
\hline
\end{tabular}

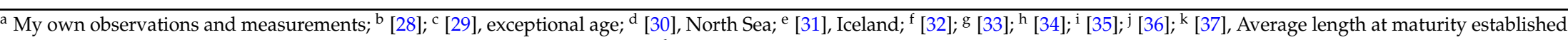
at $220 \mathrm{~mm}$ macroscopically and at $192 \mathrm{~mm}$ histologically (microscopically); ${ }^{1}$ [38], caught by B. Katgerman (Dordrecht, The Netherlands) on $5 \mathrm{May} 1995 ; \mathrm{m}$ [39]; ${ }^{\mathrm{n}}$ [40], Adriatic Sea; [41]; $\mathrm{P}$ [42]; ${ }^{\mathrm{q}}$ [43], Adriatic Sea. TL: Total fish length in $\mathrm{mm}$, OL: otolith length in $\mathrm{mm}$.

Table 2. Synopsis of depth distribution and schooling characteristics of recent trisopterine Gadidae.

\begin{tabular}{|c|c|c|c|c|c|c|}
\hline Species & Preferred Depth & Common Depth & $\begin{array}{l}\text { Depth in Bays } \\
\text { and Estuaries }\end{array}$ & $\begin{array}{l}\text { Minimum Depth } \\
\text { in Open Sea }\end{array}$ & Maximum Depth & Shoaling \\
\hline Neocolliolus esmarkii & $\begin{array}{l}\text { 100-200 m a Highest } \\
\text { abundance I-group } \\
\text { and older: } 200 \mathrm{~m}^{\mathrm{b}}\end{array}$ & $50-250 \mathrm{~m}\left(80-200 \mathrm{~m}^{\mathrm{c}}\right)$ & Few meters ${ }^{d}$ & $40 \mathrm{~m}^{\mathrm{c}}$ & $560 \mathrm{~m}^{\mathrm{e}}$ & Very large shoals \\
\hline Allotrisopterus minutus & $40-160 \mathrm{~m}^{\mathrm{f}}$ & $25-300 \mathrm{~m}^{\mathrm{c}}$ & $0.5 \mathrm{~m}^{\mathrm{g}}$ & $15 \mathrm{~m}^{\mathrm{h}}$ & $440 \mathrm{~m}^{\mathrm{i}}$ & Small shoals \\
\hline Trisopterus luscus & $30-100 \mathrm{~m}^{\mathrm{j}}$ & $3-300 \mathrm{~m}^{\mathrm{c}}$ & Few meters ${ }^{d}$ & $3 \mathrm{~m}^{\mathrm{c}}$ & $\begin{array}{c}650 \mathrm{~m}^{\mathrm{n}} \\
300 \mathrm{~m}^{\mathrm{n}}\end{array}$ & Small to large shoals \\
\hline Trisopterus capelanus & $50-120 \mathrm{~m}^{\mathrm{k}}$ & $40-250 \mathrm{~m}^{1}$ & & $0 \mathrm{~m}^{\mathrm{m}}$ & $\begin{array}{l}310 \mathrm{~m}^{\circ} \\
450 \mathrm{~m}^{\mathrm{m}}\end{array}$ & Small shoals \\
\hline
\end{tabular}

${ }^{\mathrm{a}}[31] ;{ }^{\mathrm{b}}[44] ;^{\mathrm{c}}[45] ;{ }^{\mathrm{d}}[46] ;{ }^{\mathrm{e}}[47] ;{ }^{\mathrm{f}}[33] ;{ }^{\mathrm{g}}[48]$, mainly at night; ${ }^{\mathrm{h}}[49] ;^{\mathrm{i}}[50] ;{ }^{\mathrm{j}}[16] ;{ }^{\mathrm{k}}[42] ;{ }^{1}[51] ;{ }^{\mathrm{m}}[52] ;^{\mathrm{n}}[53] ;{ }^{\circ}[54]$. 


\subsection{Neocolliolus: A Justifiable Taxon in the Gadidae Family}

\subsubsection{Introductory remarks}

Based on a number of differences the new genus Neocolliolus for Trisopterus esmarkii was erected in a mainly paleontological publication [55]. Apparently, this taxonomic change has been overlooked by many ichthyologists up to now.

There is no doubt that Neocolliolus esmarkii is more closely related to the other trisopterines than to other gadids, because the mutual external characteristics of the fishes and of the otoliths resemble one another more in comparison with other species. All trisopterines are relatively small fishes. Full-grown individuals of N. esmarkii are small, usually not larger than $26 \mathrm{~cm}$ total fish length. In the Barents Sea individuals up to $35 \mathrm{~cm}$ have been caught [32].

The otoliths of N. esmarkii differ in various important respects from the other recent trisopterine species (Figure 2, Table 3): the ostium is only slightly shorter than the cauda; the ostial colliculum is relatively long and narrows above the collum as well as at its anterior part; the collum is long with a trapezoidal or ribbon like shape; and the frontal rim of the otolith is rounded. Because of growing insight it is necessary to change and enlarge the otolith diagnosis of the genus Neocolliolus (Gaemers, 1976) in several respects.
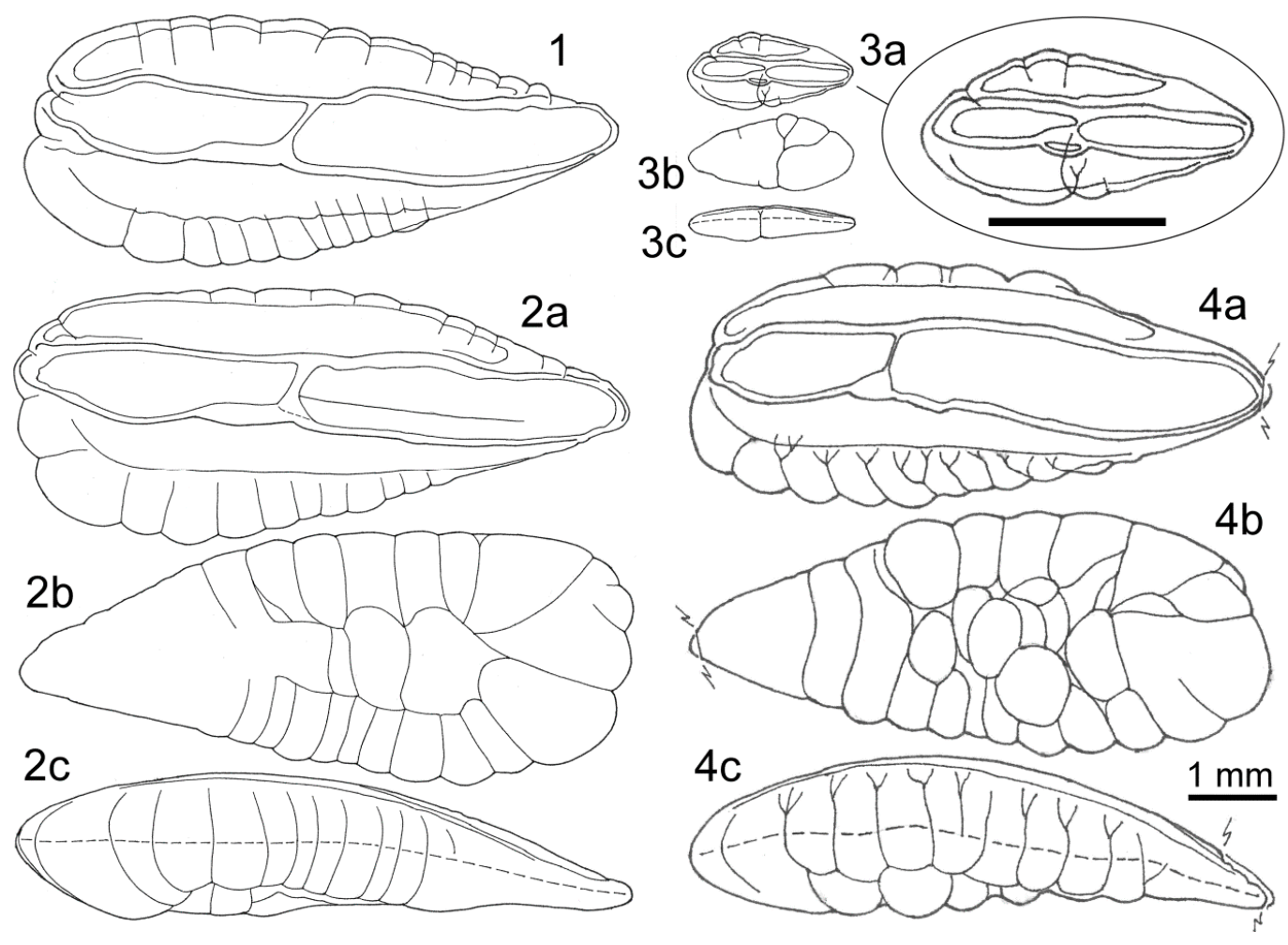

Figure 2. Differences between otolith morphology of Neocolliolus and Trisopterus. (1) Neocolliolus esmarkii, Recent, North Sea, TL 159, OL 6.85, coll. Mardik Leopold, number EU25; (2a-c) Neocolliolus esmarkii, Recent, North Sea, TL 157, OL 7.07, coll. Mardik Leopold, number EU22; (3a-c) Neocolliolus esmarkii, Recent, North Sea, TL 46, OL 1.715, mirror image, coll. Mardik Leopold, number CB1; (4a-c) New subspecies of Trisopterus capelanus, Early Miocene, Behrendorfian, Berchem Formation, Kiel Sands, borehole airfield Haamstede, The Netherlands, 132-133 m below surface, mirror image. 
Table 3. Differences and similarities between otoliths of Neocolliolus, Allotrisopterus and Trisopterus.

\begin{tabular}{|c|c|c|}
\hline Neocolliolus esmarkii Lineage & Allotrisopterus minutus Lineage & $\begin{array}{l}\text { Trisopterus luscus and } \\
\text { T. capelanus Lineages }\end{array}$ \\
\hline $\begin{array}{l}\text { Otoliths flat or slightly } \\
\text { curved lengthwise }\end{array}$ & $\begin{array}{l}\text { Otoliths slightly curved or } \\
\text { flat lengthwise }\end{array}$ & Otoliths clearly curved lengthwise \\
\hline $\begin{array}{l}\text { Inner surface slightly to } \\
\text { moderately convex lengthwise } \\
\text { and not twisted }\end{array}$ & $\begin{array}{l}\text { Inner surface usually moderately } \\
\text { convex and twisted }\end{array}$ & $\begin{array}{l}\text { Inner surface strongly convex } \\
\text { lengthwise and twisted }\end{array}$ \\
\hline Postdorsal angle usually distinct & Postdorsal angle usually distinct & Postdorsal angle usually absent \\
\hline $\begin{array}{l}\text { Strongest ornamentation: low } \\
\text { relief with low to very low knobs } \\
\text { and shallow grooves }\end{array}$ & $\begin{array}{l}\text { Strongest ornamentation: very } \\
\text { high relief with protruding knobs } \\
\text { and deep grooves }\end{array}$ & $\begin{array}{l}\text { Strongest ornamentation: very } \\
\text { high relief with protruding knobs } \\
\text { and deep grooves }\end{array}$ \\
\hline Frontal rim rounded & $\begin{array}{l}\text { Frontal rim } \pm \text { straight, nearly } \\
\text { perpendicular to long axis }\end{array}$ & $\begin{array}{l}\text { Frontal rim } \pm \text { straight, obliquely } \\
\text { running with respect to the } \\
\text { long axis }\end{array}$ \\
\hline $\begin{array}{l}\text { Collum long, trapezoidal } \\
\text { or ribbon like }\end{array}$ & Collum short, about triangular & Collum short, about triangular \\
\hline Ostium slightly shorter than cauda & Ostium clearly shorter than cauda & Ostium clearly shorter than cauda \\
\hline Cauda (nearly) straight & Cauda with S-curve & Cauda with S-curve \\
\hline $\begin{array}{c}\text { Ostial colliculum relatively long, } \\
\text { also above collum where it } \\
\text { narrows; its anterior part } \\
\text { narrows too }\end{array}$ & $\begin{array}{l}\text { Ostial colliculum relatively short, } \\
\text { regularly oval-shaped }\end{array}$ & $\begin{array}{l}\text { Ostial colliculum relatively short, } \\
\text { regularly oval-shaped }\end{array}$ \\
\hline
\end{tabular}

\subsubsection{Amended otolith diagnosis of Neocolliolus}

A small gadid genus with moderately small, rather slender and moderately thick otoliths up to a little more than $9 \mathrm{~mm}$ long. General shape oblongly pear-shaped, only slightly bent lengthwise. Inner surface slightly to moderately convex lengthwise and not twisted. Ventral portion of rostral end strongly rounded. Caudal end sharply pointed. Distinct, rounded predorsal angle at the dorsal portion of the rostral rim. Postdorsal angle usually not pronounced, but well visible especially in medium-sized otoliths. Parts between caudal point and postdorsal angle, and between postdorsal and predorsal angle usually straight. Sulcus acusticus wide and shallow, and nearly straight; it is nearly completely filled with the caudal and ostial colliculi; cauda only slightly bent towards the ventral rim. Ostial colliculum only slightly shorter than caudal colliculum. Posterior part of ostial colliculum narrow above collum. Anterior part of ostial colliculum also narrowed, except in the largest otoliths. Rather big trapezoidal to ribbon like collum with a long base and only present on the ventral part of the sulcus acusticus. No pseudocolliculum in the collum of adults, but early juvenile otoliths may have a pseudocolliculum (Figure 2(3a)). Ornamentation on outer surface and along the rims weakly developed with low or even very low, rounded knobs, and shallow grooves on the outer surface and along the rims fading away in larger otoliths. Ventral part of otolith clearly thicker than dorsal part.

\subsubsection{Other distinguishing characteristics of Neocolliolus}

The special taxonomic position of this species cannot only be shown by the otoliths but also many characteristics of the fishes are different (Figure 3, Table 4). Several differences are connected with a different way of life and ecology of this species compared with the other trisopterines. The position of the mouth shows that N. esmarkii is equipped for foraging in mid water, and not on the sea-bottom like the other species. This is confirmed by the food that is regularly found in the stomachs of this species. It feeds mostly on planktonic crustaceans (copepods, euphausiids, shrimps and amphipods), but also on small fish and various eggs and larvae [31,44,56,57]. The much higher number of gill rakers [16] shows that this species can filter smaller prey than the other trisopterines. In their diagnosis for the 
genus Cohen et al. [49] mention a well-developed chin barbel for all species assigned to Trisopterus, but this is not correct. N. esmarkii has a very small chin barbel. This feature and the shorter pelvic fin are in accordance with a mainly mesopelagic life as contrasted with the other trisopterines that live close to the sea-bottom and feed just above it or in it. The more streamlined body, the longer pectoral fin, the lower dorsal and anal fins, and the short interspaces between the dorsal fins probably all indicate that N. esmarkii is able to swim faster than the other trisopterine species. It is also recognized by a clearly counter shaded coloration with a dark, grey-brown dorsum, dull silvery sides, and a white belly $[21,49]$.
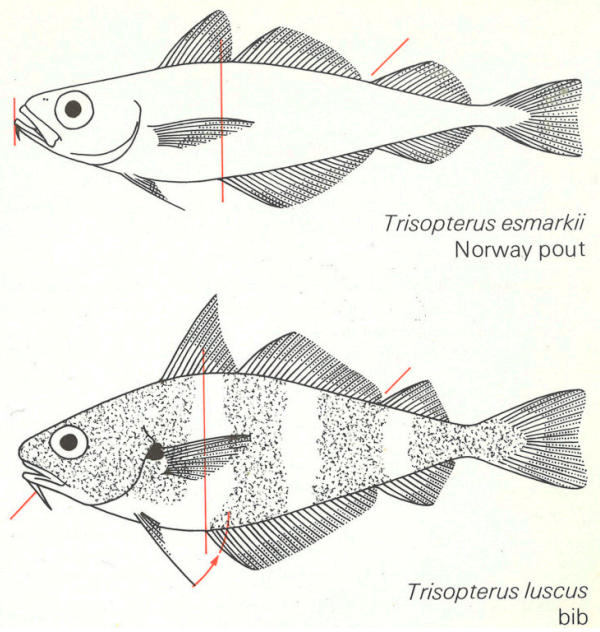

Figure 3. External features of Neocolliolus and Trisopterus showing important differences indicated with red lines. From Wheeler (1978) [45].

Table 4. Distinguishing external and ecological characteristics of Neocolliolus esmarkii with regard to the other recent trisopterine species.

\begin{tabular}{cc}
\hline Neocolliolus esmarkii & Other Recent Trisopterine Species \\
\hline $\begin{array}{c}\text { Streamlined, slender body shape with a lower head } \\
\text { profile and deepest body part more backwards } \\
\text { Lower jaw slightly longer than upper jaw }\end{array}$ & $\begin{array}{c}\text { Less streamlined body shape with a higher head } \\
\text { profile and deepest body part more forwards } \\
\text { Chin barbel short and thin }\end{array}$ \\
Pelvic fin relatively short & Chin barbel long and thick \\
Pectoral fin relatively long & Pelvic fin relatively long \\
Pectoral fin relatively short \\
Dorsal and anal fins lower and more rounded \\
Short interspaces between the dorsal fins \\
Eye relatively large & Dorsal and anal fins higher and more pointed \\
High number of gill rakers (33-43) & No interspaces between dorsal fins \\
Benthopelagic to mesopelagic & Eye relatively smaller \\
Food: mainly planktonic crustaceans & Low number of gill rakers (14-22) \\
Demersal
\end{tabular}

\subsection{Trisopterus capelanus Is a Separate Species}

The taxonomic status of Trisopterus capelanus (Lacepède, 1800) has been discussed much in the course of time. Originally described as a species, T. capelanus, it nowadays is regarded by most biologists as a subspecies of A. minutus, following Svetovidov's monograph [1,2] on the Gadiformes (published in English in 1962). This view is also hold by the authors of the last published big monograph of the Gadiformes [49]. Confusion was already created by Linnaeus [58] mentioning Gadus minutus only from the Mediterranean Sea, but he took this erroneously from Artedi [59] who described this species also from the Atlantic (Svetovidov 1973). It is, therefore, unclear which species Linnaeus meant under the name Gadus minutus. Müller [60] decided to give this name to fishes from Danish waters (see [2]), 
and from that time onwards ichthyologists always meant with Gadus minutus the so-called poor cod living in the Northeastern Atlantic and the North Sea. This explains why Müller by various taxonomists is mentioned as the author of G. minutus, but this is not correct. According to Lacepède [61], G. capelanus is living in the Mediterranean Sea as well as in the Atlantic Ocean. Thus, both species were said to occur in the same large area, adding more fuel to the confusion. Several taxonomists, especially in the past, didn't know the right authorship of G. capelanus, and ascribed this taxon erroneously to Rafinesque-Schmaltz [62] or Risso [63]. Otherwise, sometimes T. capelanus is considered a subspecies of T. luscus [64]. In Tuset et al. [65] the adult otolith from the western Mediterranean Sea named Trisopterus minutus on their figure 32(B3) belongs unmistakably to T. capelanus, whereas the other otoliths from the north-eastern Atlantic on their figure 32(B1, B2) are indeed A. minutus.

Svetovidov [1,2] was of the opinion that $T$. capelanus was very close to A. minutus in external form and osteology, although he knew the findings of Fage [66], and Chaine and Duvergier [67]. Therefore he decided to place both taxa in one species. Svetovidov had only three specimens of $T$. capelanus at his disposal, and it is very likely that he has never seen a fresh fish of this species. However, if he would have read Fage's article carefully, he should have come to another conclusion. Svetovidov even mentions that Chaine and Duvergier [67] indicate differences in the external characteristics of the fishes as well as of the otoliths of T. capelanus, A. minutus and T. luscus; in the latter paper even illustrations of the otoliths have been published. Apparently Svetovidov was unaware of the possibilities of otoliths to discriminate between closely related species in most bony fish families, otherwise he probably would have come to another decision.

Although the fishes of A. minutus and T. capelanus resemble one another much at first glance, because externally both are slender and have about the same maximum size, there are much more important differences. A. minutus is more slender than T. capelanus; the upper part of its head is less steeply rising; its curvature of the lateral line is less strong, its first anal fin is shorter [66]. Its number of fin rays of the second and third dorsal fins and the second anal fin is distinctly larger, and the same applies to its number of gill-rakers and vertebrae [1,2].

Moreover, the otoliths of these species differ very much. Those of A. minutus are generally much shorter, higher and thicker than those of T. capelanus. There is only little overlap in the length-height ratios for otoliths with OL greater than $7 \mathrm{~mm}$ (A. minutus: TL 49-273; T. capelanus: TL 66-288) (Figure 4). There is somewhat more overlap in the length-thickness ratios of the otoliths of these species; the greatest differences occur at OL between 5 and $10 \mathrm{~mm}$ (Figure 5). The postdorsal angle is always well developed in A. minutus otoliths, and usually absent in T. capelanus. In medium-sized to large otoliths the margin between the postdorsal angle and the posterior point is nearly always concave in A. minutus, and nearly never concave in T. capelanus. The angle between the rostral margin and the greatest length of the otolith is greater in A. minutus, usually around $80^{\circ}$; in T. capelanus it is on an average about $60^{\circ}$. The mean OL-OH and OL-OT curves of both species that can be constructed show concave shapes in the measured interval, but the curves for T. capelanus are stronger bent and those for A. minutus are straighter, thus indicating that the otoliths of T. capelanus grow more allometrical.

The otoliths of $T$. capelanus more strongly resemble those of $T$. luscus in their general shape than those of $A$. minutus. The postdorsal angles are absent or weakly developed in both species. The inclination of their rostral rims is also similar, rather variable and largely overlapping in the two species, although that of $T$. capelanus on an average is a little bit less steep. The most obvious difference is that otoliths of T. capelanus are more slender than those of $T$. luscus, apparently reflecting the more slender external shape of the fishes of T. capelanus. The otoliths of the latter species are also larger with respect to the size of the fish (Figure 6). This is in agreement with the observed general tendency, that smaller species within a closely related group have relatively larger otoliths. This is in line with relatively larger eyes and various other organs in smaller species as well as in smaller individuals of a certain species. The fact is, that the maximum total fish length of T. capelanus (about $32 \mathrm{~cm}$ ) remains much smaller than that of T. luscus (46 to $49 \mathrm{~cm}$ ). 
Figure 6 also shows, that OL/TL ratio of both species is not linear but allometric: the convex curves that can be constructed for the mean values demonstrate that otolith lengths of both species become relatively smaller in larger fishes. Although the smallest specimens are not available, it is logical thinking that the curves must start at the zero point of the graph. For T. luscus Merayo and Villegas [68] however suggest that the OL/SL ratio (which is comparable with the OL/TL ratio) can be considered linear, but although they do not present a graph, their mean line clearly cannot start at the zero point because of the equations in the upper part of their Table 1 . Their conclusion that the mean development of the OL/SL ratio follows a straight line is not true. In the last sentence of their section on otolith growth on page 117, they were aware of the negative allometry of this relationship because the power functions proved significantly different from 1 .

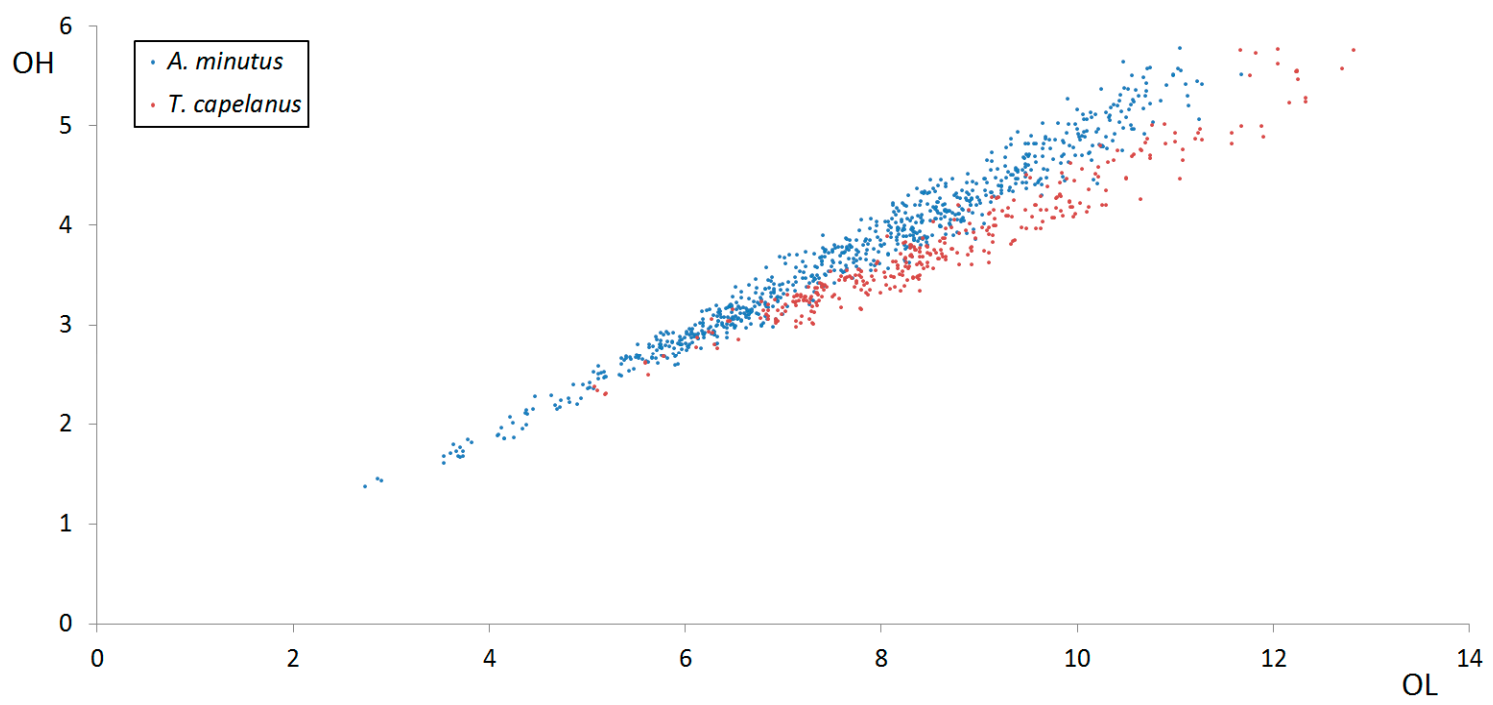

Figure 4. The ratios of otolith length $(\mathrm{OL})$ and otolith height $(\mathrm{OH})$ compared between Trisopterus capelanus $(n=338)$ and Allotrisopterus minutus $(n=764)$. OL and $\mathrm{OH}$ in $\mathrm{mm}$.

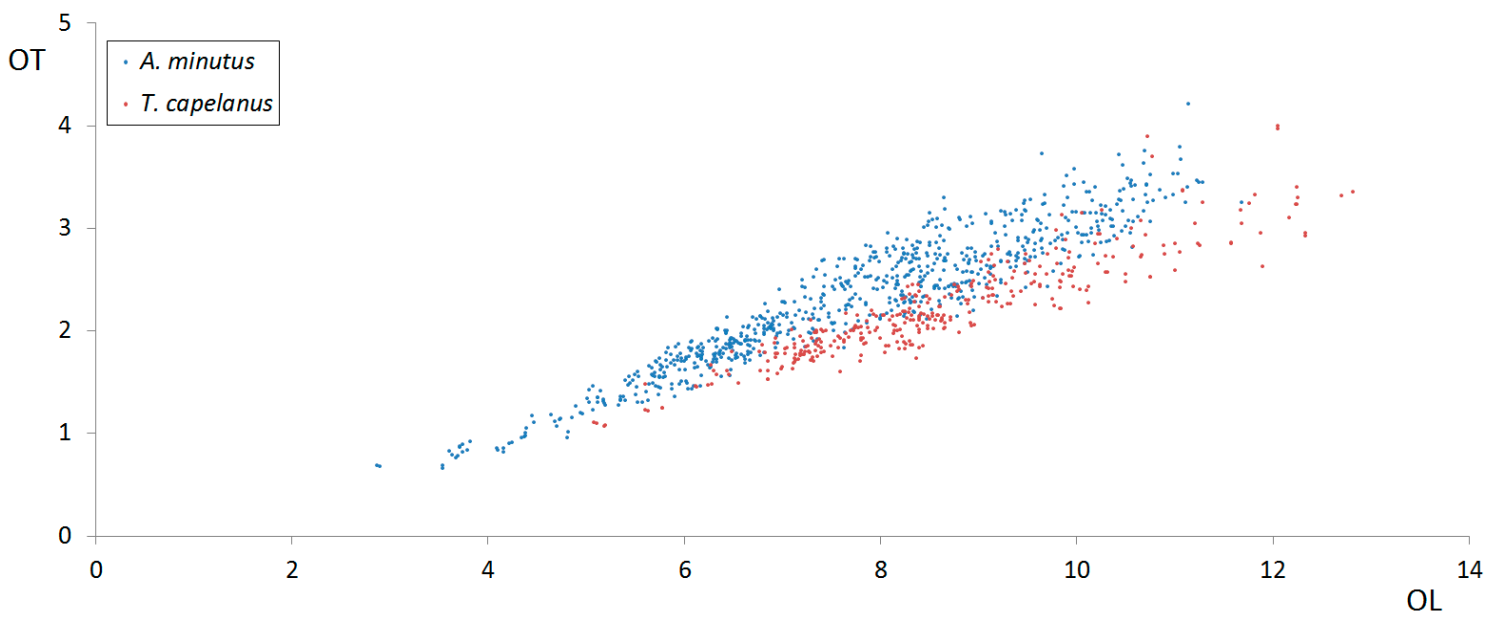

Figure 5. The ratios of otolith length (OL) and otolith thickness (OT) compared between Trisopterus capelanus $(n=337)$ and Allotrisopterus minutus $(n=741)$. OL and $\mathrm{OH}$ in $\mathrm{mm}$.

The ornamentation of the outer surface of the otoliths of $T$. luscus culminates in a clearly stronger relief in medium-sized specimens: the knobs are then extremely high and the sharp grooves are very deep. The maximum expression of the ornamentation in T. capelanus is more normal and its relief smoothens earlier in later life. In T. luscus the length curvature of the outer surface is more regular, so that the thickest point of the otolith is not elevated above its surroundings. In larger otoliths of 
T. capelanus, in contrast, the thickest point is often clearly protruding forming an umbo. Although there might be some overlap in the variability of some characteristics of the otoliths of the two species, individual otoliths of these species usually can be distinguished rather easily. Based on many external characteristics of the fishes and of the otoliths it is obvious that T. luscus and T. capelanus are more related to one another than to the other species of the trisopterines, and they can be considered sister species. Genetic data support this close relationship very well: both the complete mitochondrial DNA of cytochrome $b$ and the nuclear DNA of the rhodopsin genes point to a much closer relationship of T. luscus and T. capelanus than any other combination of two of the four trisopterine species [21,22]. This is a strong confirmation of earlier research in which was found that both species shared the highest number of loci with the same alleles extracted from muscle and liver tissue [18].

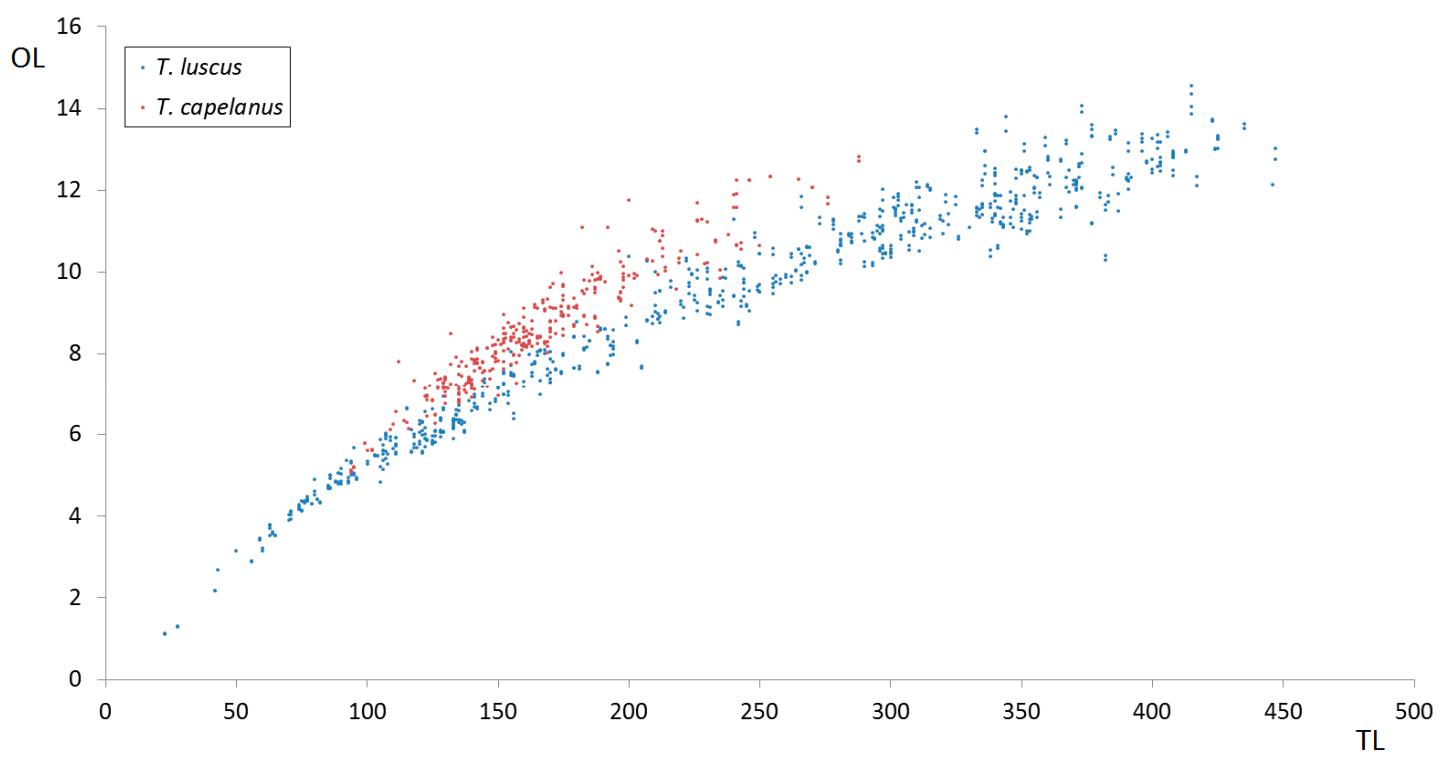

Figure 6. The ratios of otolith length (OL) and total fish length (TL) compared between Trisopterus capelanus $(n=328)$ and Trisopterus luscus $(n=767)$. OL and TL in mm.

\subsection{Allotrisopterus, a New Genus for Trisopterus Minutus}

\subsubsection{Allotrisopterus n. gen.}

Type species: Gadus minutus Linnaeus, 1758;

Derivatio nominis: Allos (Greek): another one; tris (Greek): thrice; pteron (Greek): wing, fin. Diagnosis: External characteristics. A gadid genus of small trisopterine fishes (total fish length up to $26 \mathrm{~cm}$ ) with a slender shape. Head profile low. Origin of first anal fin beneath the space between first and second dorsal fins or anterior to it. First anal fin only slightly longer than second anal fin.

Meristic characteristics. Numbers of gill rakers, vertebrae, pterygiophores of 3rd dorsal fin and pterygiophores of 2nd anal fin intermediate between N. esmarkii and T. luscus/T. capelanus. Number of 2nd dorsal fin pterygiophores close to N. esmarkii. Number of 1st dorsal fin pterygiophores close to T. luscus/T. capelanus.

Otoliths. Outline short and high. Flat or slightly curved lengthwise. Inner surface moderately convex lengthwise. Postdorsal angle usually distinct. Frontal margin nearly perpendicular to long axis. 


\subsubsection{Remarks of justification}

There are a series of arguments for the erection of a new genus for Trisopterus minutus, based on external characteristics, meristics, otoliths and genetics.

Differences in external characteristics at first glance are not very obvious between $A$. minutus and T. capelanus. A. minutus is somewhat more slender than T. capelanus. The head profile in A. minutus is lower than in T. luscus and T. capelanus, and comes closer to that in N. esmarkii. In A. minutus the origin of the first anal fin is beneath the space between the first and second dorsal fins or anterior to it; about the same positioning is present in N. esmarkii [45]. In T. luscus and T. capelanus the origin of the first anal fin is halfway beneath the first dorsal fin. The first anal fin is only slightly longer than the second anal fin in A. minutus, whereas the first anal fin in T. luscus and T. capelanus is much longer than the second one.

The meristic characteristics show an intermediate position between N. esmarkii and the other trisopterines, especially the numbers of gill rakers, of vertebrae, of pterygiophores of the 3rd dorsal fin and of pterygiophores of the 2nd anal fin (Table 5). The number of 1st dorsal fin pterygiophores is more in the range of the T. luscus and T. capelanus, the number of 2 nd dorsal fin pterygiophores is more in agreement with N. esmarkii.

Table 5. Meristics showing the intermediate position of Allotrisopterus minutus between Neocolliolus and Trisopterus (after reference [20]); numbers of vertebrae and gill rakers supplemented with data given in [1,2].

\begin{tabular}{ccccc}
\hline Meristics & N. esmarkii & A. minutus & T. capelanus & T. luscus \\
\hline Number of vertebrae & $51-55$ & $47-51$ & $45-48$ & $46-49$ \\
Number of gill rakers & $33-37$ & $24-28$ & $15-21$ & $18-23$ \\
\hline \multicolumn{7}{c}{ Number of dorsal fin pterygiophores } \\
1st dorsal fin & $15-17$ & $13-15$ & $12-14$ & $13-14$ \\
2nd dorsal fin & $26-28$ & $24-28$ & $18-23$ & $22-25$ \\
3rd dorsal fin & $28-30$ & $22-25$ & $17-21$ & $19-23$ \\
1st anal fin & $31-35$ & $29-34$ & $26-32$ & $31-36$ \\
2nd anal fin & $27-30$ & $23-25$ & $17-22$ & $19-22$ \\
\hline
\end{tabular}

The otoliths of A. minutus also show an intermediate position between Neocolliolus and Trisopterus (Table 3). The differences with Neocolliolus were already mentioned in the section on Neocolliolus as a justifiable taxon. The otoliths of A. minutus differ from those of T. luscus and T. capelanus by its distinct postdorsal angle, its steep frontal margin, its flatter side view, and its less convex inner surface. The shape of the otoliths of the sister species T. luscus and T. capelanus correlates very well with the shape of the fishes: both otoliths and fishes of T. capelanus are more slender than in T. luscus. If A. minutus were a sister species of the other two, it should have had even somewhat more slender otoliths than T. capelanus. However, A. minutus has the shortest and highest otoliths of all Recent trisopterine species.

Since the beginning of the 21st century a series of papers have been published about genetic characteristics of trisopterine species [18-22,69]. Allele frequencies at polymorphic loci obtained from muscle and liver tissues by Mattiangeli et al. [18] were not conclusive enough to unravel the closest relationship of $A$. minutus with one of the other trisopterines. They found that $A$. minutus and $N$. esmarkii share the most common allele at GPI-2*, while the most common allele at $A D A-3^{*}$ is shared by P. minutus and T. capelanus. Therefore, these data are contradictory. According to their calculated Nei's genetic distance Mattiangeli et al. [18] concluded that N. esmarkii would be more closely related to T. luscus and T. capelanus than to A. minutus. Their dendrogram of the intraspecific relationships among $A$. minutus from the various investigated areas (ibidem, Figure 3 ), however, shows an incorrect picture of the most related connections, giving proof of their indecisive phylogenetic data. Based on molecular data from the mitochondrial cytochrome $b$ gene and the nuclear rhodopsin gene Delling et al. [21] and Gonzalez et al. [22] firmly concluded that A. minutus and N. esmarkii are more closely related to one another than to the sister species T. luscus and T. capelanus. In addition, 
Carr et al. [68] come to the conclusion that A. minutus is more closely related to N. esmarkii than to T. luscus based on portions of two mitochondrial DNA genes (cytochrome $b$ and cytochrome oxidase I). The data in $[21,22,70]$ are in full agreement with the data obtained from otolith characteristics.

All above-mentioned data taken together justify the erection of the new genus Allotrisopterus. Fossil trisopterine otoliths from the Tertiary affirm this (see section Evolution of trisopterines). The general resemblance between A. minutus and T. capelanus has to be attributed to convergence.

\subsection{Otoliths from Bottom Samples of the Ría de Arosa (north-western Spain)}

Among the mollusks and other marine animal remains in Recent and Holocene sediments Cadée [71] found otoliths in and off the Ría de Arosa in Galicia, north-western Spain at 19 stations (Figure 7). Ten bony fish species were recognized by means of otoliths: three gadids, one merluccciid, five gobiids and a sole (Table 6). Apart from several specimens of Lesueurigobius friesii the gobiids are restricted to depths between 7 and $10 \mathrm{~m}$ in the inner central bay and the marginal shallow zone. The one otolith of a sole has been found at $7 \mathrm{~m}$ depth in the marginal shallow zone. The European Atlantic hake is known from a juvenile otolith in one sample in the outer central bay. The gadid otoliths all belong to three species of trisopterines (Figure 8, Table 6). The most common species is A. minutus (Figure $8(5 \mathrm{a}-\mathrm{c}, 6 \mathrm{a}-\mathrm{c})$ ) occurring at 9 stations in the outer central bay, the oceanic zone and the marginal deep zone bordering the outer central bay. T. capelanus has been found in the same environments, but is less common, occurring at 5 stations (Figure $8(1 \mathrm{a}-\mathrm{c}, 2 \mathrm{a}-\mathrm{c})$ ). T. luscus has a wider distribution: it occurs in the same environments as the other two trisopterine species, but has also been found in the middle central bay and the marginal shallow zone (Figure 8(3a-c,4a-c)). Except for the shallow occurrence of all Trisopterus and Neocolliolus species in special environments like estuaries (Table 2), T. luscus is known to live in the shallowest waters in the north-eastern Atlantic and the North Sea. The presence of this species in shallower waters in the Ría de Arosa is in agreement with this. Despite its wider distribution, T. luscus has been found at no more than 6 stations. 


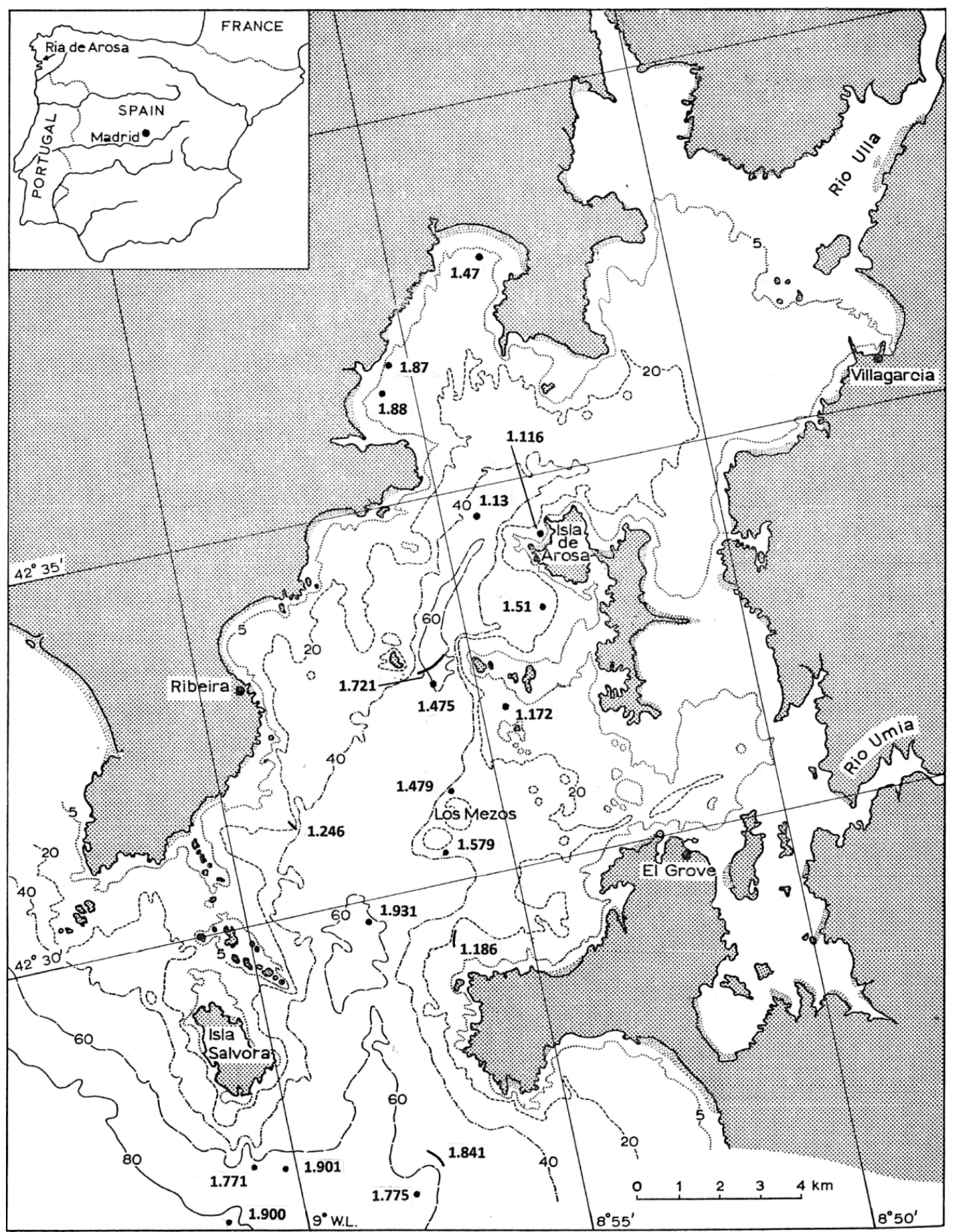

Figure 7. Map of the Ría de Arosa, Galicia, Northwest Spain with the stations at which otoliths were found in sediment samples. The stations are indicated by dots or lines. Modified after Cadeé [71]. 
Table 6. Distribution of otoliths in sea-bottom samples in the Ría de Arosa, Galicia, northwestern Spain.

\begin{tabular}{|c|c|c|c|c|c|c|c|c|c|c|c|c|c|c|c|c|c|c|c|}
\hline \multirow{3}{*}{$\begin{array}{c}\begin{array}{c}\text { Ecological Zonation } \\
\text { (Cadée, 1968) }\end{array} \\
\text { Station } \\
\text { Depth in } \mathrm{m}\end{array}$} & \multicolumn{2}{|c|}{$\begin{array}{c}\text { Inner } \\
\text { Central Bay }\end{array}$} & \multicolumn{2}{|c|}{$\begin{array}{c}\text { Marginal } \\
\text { Shallow Zone }\end{array}$} & \multicolumn{3}{|c|}{ Middle Central Bay } & \multirow{2}{*}{$\begin{array}{c}\begin{array}{c}\text { Marginal } \\
\text { Deep } \\
\text { Zone }\end{array} \\
246\end{array}$} & \multicolumn{7}{|c|}{ Outer Central Bay } & \multicolumn{4}{|c|}{ Oceanic Zone } \\
\hline & 87 & 88 & 47 & 116 & 13 & 51 & 172 & & 186 & 475 & 479 & 579 & 721 & 931 & 771 & 775 & 841 & 900 & 901 \\
\hline & $7-8$ & 10 & 7 & 12 & 54 & 24 & 8 & 15-35 & $18-20$ & 60 & $35-38$ & $35-40$ & $50-60$ & c. 62 & 68 & 50 & $40-55$ & 85 & 60 \\
\hline Trisopterus capelanus & & & & & & & & 1 & & & & & 1 & 1 & & & 2 & 5 & \\
\hline Trisopterus luscus & & & & 1 & & & 1 & & & & 1 & & & & & & 1 & 6 & 1 \\
\hline Allotrisopterus minutus & & & & & & & & 1 & 1 & 1 & & 1 & & & 2 & 1 & 2 & 24 & 2 \\
\hline Merluccius merluccius & & & & & & & & & & & & & 1 & & & & & & \\
\hline Aphia minuta & & & 1 & & & & & & & & & & & & & & & & \\
\hline Lesueurigobius friesii & & 2 & & & 4 & 1 & & & & & & & & & & & & & \\
\hline Lesueurigobius sanzoi & & 2 & & & & & & & & & & & & & & & & & \\
\hline Pomatoschistus minutus & & 5 & 9 & & & & & & & & & & & & & & & & \\
\hline Thorogobius ephippiatus & 1 & & & & & & & & & & & & & & & & & & \\
\hline Solea solea & & & 1 & & & & & & & & & & & & & & & & \\
\hline
\end{tabular}




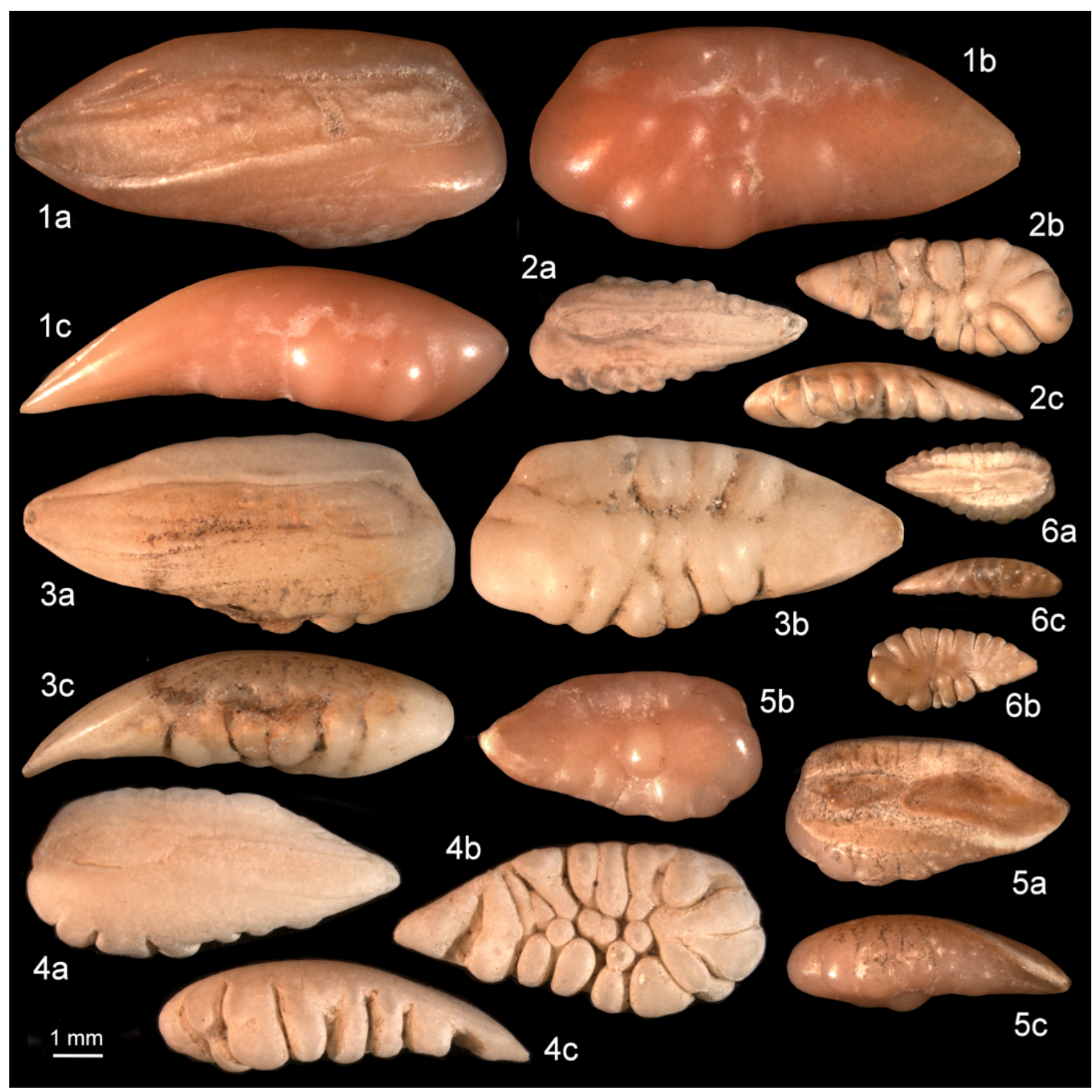

Figure 8. Trisopterine otoliths from the Ría de Arosa, Galicia, Northwestern Spain. (1a-c) Trisopterus capelanus, station 1.841, 40-55 m depth, MAB 001328; (2a-c) T. capelanus, station 1.721, 50-60 m depth, MAB 001327; (3a-c) T. luscus, station 1.246, 15-35 m depth, MAB 001321; (4a-c) T. luscus, station 1.901, 60 m depth, MAB 001325; (5a-c) A. minutus, station 1.841, 40-55 m depth, MAB 001313; (6a-c) A. minutus, station 1.246, 15-35 m depth, MAB 001308.

At two stations in the oceanic zone at depths between 40 and $85 \mathrm{~m}$, the three trisopterine species co-occur in the same samples (Table 6). The highly overlapping distribution of these species is additional proof that the three species are and were living together in this area, what was not known before. Thus, Lacepède [61] turns out to be right that G. capelanus is also living in the Atlantic Ocean.

\subsection{Geographical and Depth Distribution}

Trisopterus luscus (Figure 9). This species has a large geographical distribution. It is most common from the Nordfjord $\left(62^{\circ} \mathrm{N}\right)$ in Norway to the Skagerrak, in the whole North Sea shallower than $100 \mathrm{~m}$, around the entire United Kingdom and Ireland, south of the Faroe Islands, on Rockall Bank, in the English Channel, along the Atlantic coast of France and Spain up to the northern part of Portugal. 


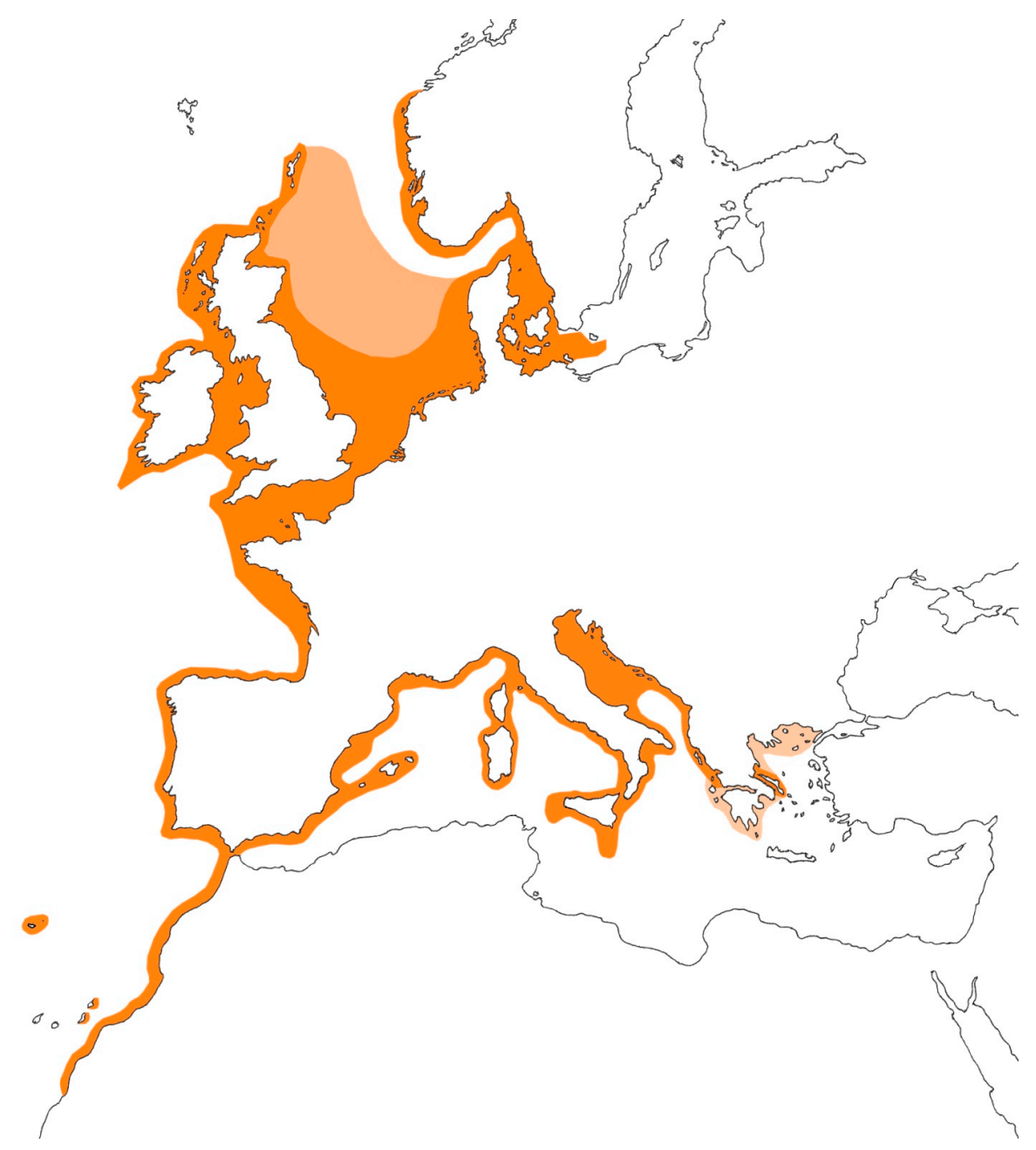

Figure 9. Present geographic distribution of Trisopterus luscus. Lighter orange in the North Sea means lesser abundance. Very light orange around Greece: probable distribution, but not yet proven.

The most northern location of this species is the Romsdalsfjord in Norway $\left(62^{\circ} 44^{\prime} \mathrm{N}\right)$. It is less abundant in the Kattegat and the south-westernmost part of the Baltic Sea, in the deeper parts of the North Sea, from central Portugal to the south of Morocco in the Atlantic (to $25^{\circ} \mathrm{N}$ ), around Madeira and east of Lanzarote and Fuerteventura (Canary Islands), around some of the Canary Islands, in the shallower depths of the western Mediterranean Sea up to the northern part of Tunisia and around Sicily, in the entire northern part of the Adriatic Sea shallower than $200 \mathrm{~m}$ [72]. It also occurs along the more southeastern coast of Italy, thus along the entire coast of Italy. According to the FAO aquatic species distribution map of T. luscus [73] this species continues its occurrence along the eastern coast of the Adriatic Sea (Kroatia, Montenegro, Albania) up to the Gulf of Corinth in Greece.

And now it has also been recognized by means of otoliths in the Euvoikos Gulf, the Orei Channel and the Pagassitikos Gulf along the central eastern coast of Greece, which have an open connection with the Aegean Sea. Otoliths of 15 fishes of T. luscus appeared to be present among a collection of otoliths from 193 fishes identified as T. capelanus and obtained from Chrissy-Yanna Politou. Adult fishes of this species occur here mainly below 100 meters depth and younger fishes were not found shallower than 50 meters. The occurrence east of central Greece stimulates the supposition that it also occurs on the deeper parts of the shelf around southern Greece. There might be several reasons why T. luscus has not yet been recognized in this area: it is more rare there, it lives in deeper water where the local fishermen usually are not fishing, it was not expected there, and perhaps it lacks the characteristic distinct broad dark bars; and thus it has been confused there with T. capelanus. 
These Greek T. luscus otoliths have a relatively stocky shape like other Mediterranean specimens of this species (Figure 10(1a,b,2a-c)) and can easily be distinguished from the T. capelanus otoliths in the same area.

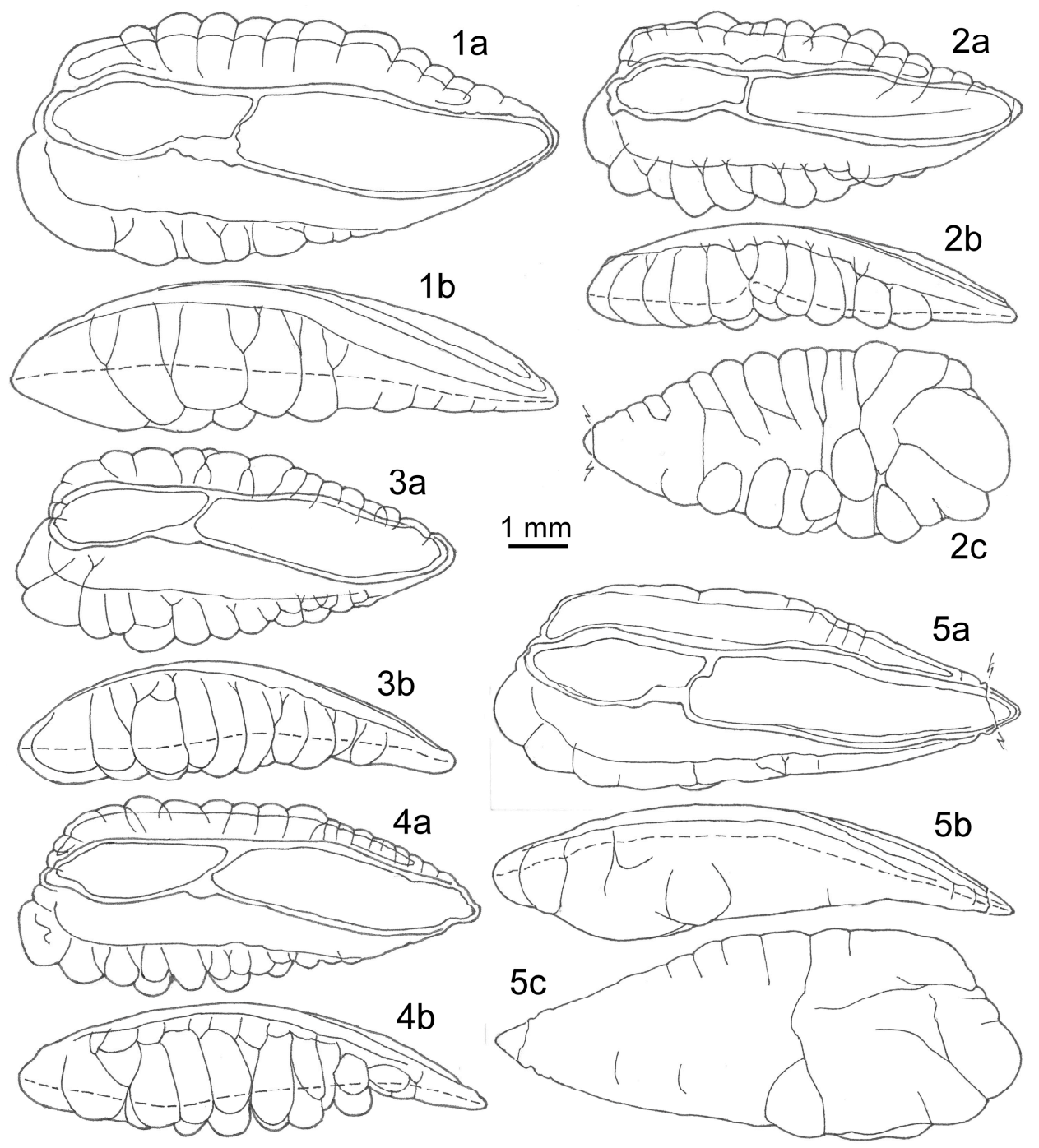

Figure 10. Trisopterus luscus otoliths from Greece and the North Sea, and (most likely) Trisopterus capelanus otolith, Faroe Islands. $(\mathbf{1} \mathbf{a}, \mathbf{b}, \mathbf{2 a}-\mathbf{c})$ T. luscus, Ovvoïkós Channel, east of mainland of Greece, below $100 \mathrm{~m}$ depth, mirror images; (1a,b) female, TL 245, OL 9.21; (2a-c) female, TL 149, OL 7.28; (3a,b, $\mathbf{4 a}, \mathbf{b})$ T. luscus, North Sea, coll. M. Leopold, numbers AR 32 and AR 31, respectively; (3a,b) TL 166, OL 7.34; (4a,b) TL 163, OL 7.74; (5a-c) Most probably T. capelanus, Faroe Bank, Faroe Islands, cruise 03680025, number 5092, male, TL 181, TW 55, OL c. 8.45, mirror image.

In the southern part of the North Sea T. luscus otoliths are fairly variable in shape; the same stocky shape as in the Mediterranean can be found there (Figure 10(3a,b)), but usually the otoliths are somewhat more slender (Figure 10(4a,b)).

Trisopterus capelanus (Figure 11). The main area of this species nowadays is the Mediterranean Sea. It is abundant in the entire western Mediterranean Sea occurring there along the Spanish, Italian, Moroccan and Algerian coasts, the northern coast of Tunisia, and around Corsica, Sardinia and Sicily. It is also abundant in the Adriatic Sea and the northern Aegean Sea. It is more rare in the southern part of the Aegean Sea and along the south coast of Turkey. According to Cohen et al. [49] it also occurs along eastern coasts of the eastern Mediterranean up to and including the Nile delta. It is probably absent along the coasts of Libya and Egypt west of the Nile delta. Svetovidov [1,2] mentions 
this species also from the Atlantic Ocean at the Strait of Gibraltar. It also occurs along the Moroccan Atlantic coast [16].

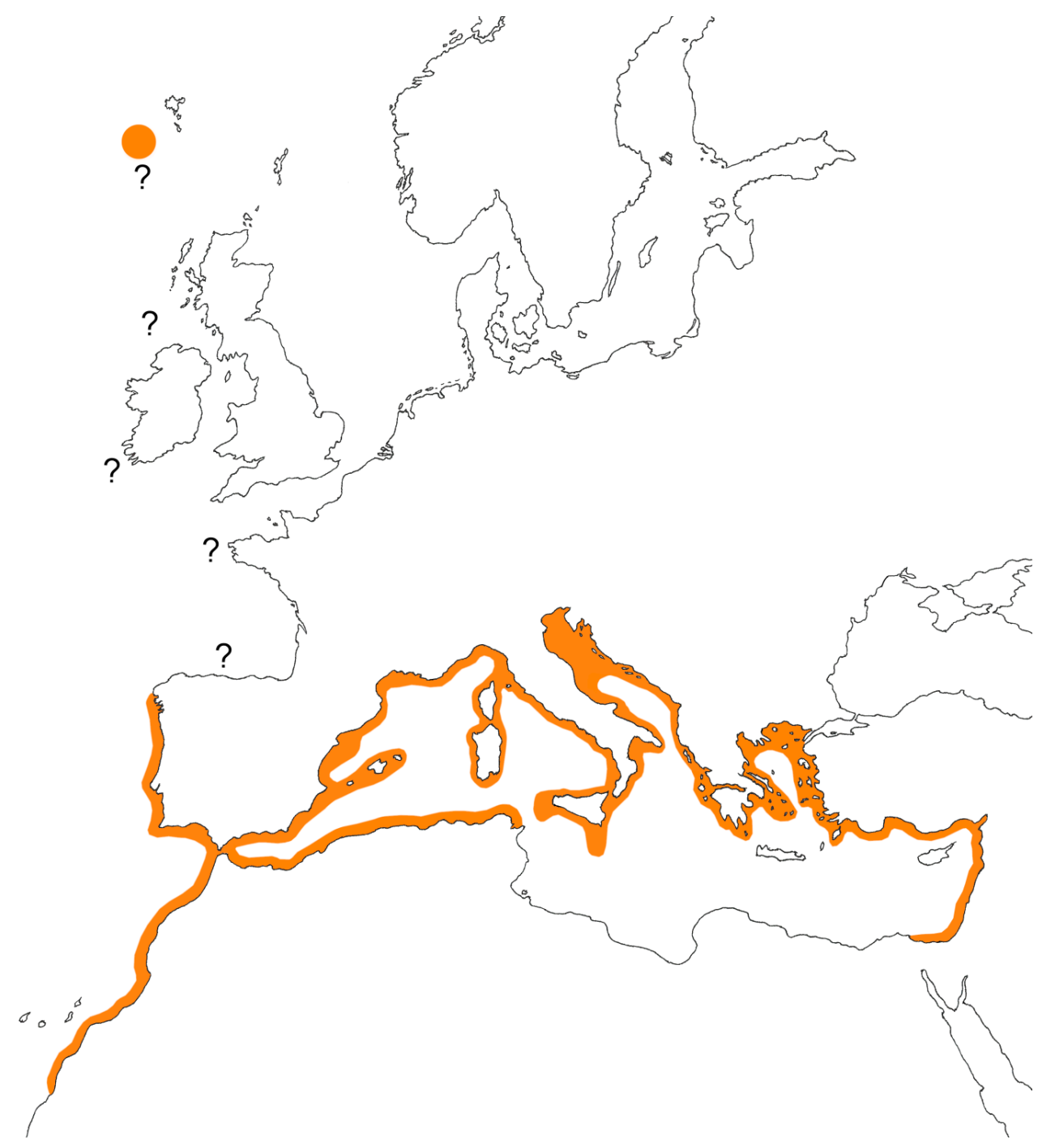

Figure 11. Present geographic distribution of Trisopterus capelanus. The occurrence southwest of the Faroe islands is only based on one specimen. The most likely route to there is west of Great Britain or even west of Ireland, indicated with question marks.

The occurrence in the Atlantic Ocean however is greater than published up till now. On 11th September, 1972, I collected otoliths from a fish with a total length of $250 \mathrm{~mm}$ in Salir do Porto, a small fishing-village belonging to the municipality of Caldas da Rainha, about $75 \mathrm{~km}$ north of Lisbon in Portugal, that clearly belong to this species (Figure 12(1a-c)) (collection P. Gaemers). Some of the fishes from Portugal, illustrated by Assis [74] and Andrade da Silva [75] as T. luscus, evidently belong to $T$. capelanus, because the otoliths show the typical slender shape of this species. It occurs even farther north, at least to $42^{\circ} 30^{\prime} \mathrm{N}$, because I could identify without difficulty several Holocene to Recent otoliths as T. capelanus that were found from sea floor sediments in front of the Ría de Arosa and the outer part of this Ría off the coast of north-western Spain (Figure 8(1a-c,2a-c)). There it co-occurs with T. luscus and T. minutus, two times even in the same sediment samples (Table 6). Fresh fish of T. capelanus along the Portuguese and Spanish Atlantic may be more easily mistaken as T. minutus, because both species are slender and lack the dark vertical bars, which are usually present in subadult and smaller specimens of T. luscus. 


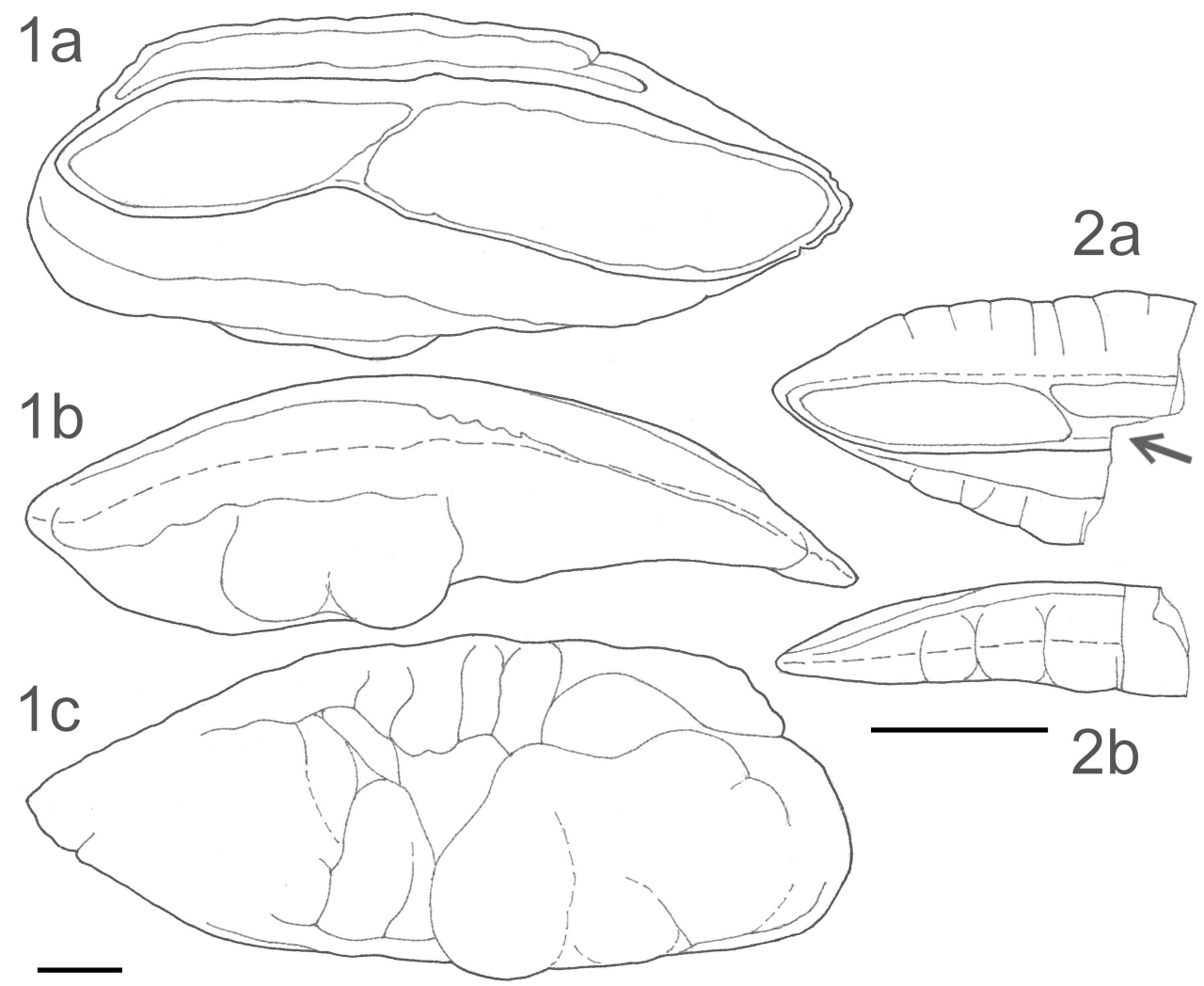

Figure 12. (1a-c) Trisopterus capelanus otolith from Salir do Porto, Portugal, TL $250 \mathrm{~mm}$, coll. P. Gaemers; (2a,b) Incomplete fossil Neocolliolus esmarkii otolith, off southern Morocco $\left(28^{\circ} 56^{\prime} 57^{\prime \prime} \mathrm{N}, 12^{\circ} 30^{\prime} 56^{\prime \prime} \mathrm{W}\right.$, depth 524 m), coll. P. Gaemers; (1a,2a) Inner surfaces, $(\mathbf{1 b}, \mathbf{2 b})$ Ventral views, $(\mathbf{1 c})$ outer surface; the arrow points to the partially preserved, ventrally situated collum. The bars represent one mm.

Furthermore, I discovered an otolith that resembles those of T. capelanus the most (Figure 10(5a-c)) among a large number of $A$. minutus otoliths from the Faroe Bank, southwest from the Faroe Islands $[33,76]$. The otolith is easily distinguishable because it is much more slender in shape than those of $A$. minutus, and can impossibly belong to this species. This otolith is also much too slender and too smooth for T. luscus as it is found in the North Sea (compare Figure 10(4a,b)). This otolith is even more slender than other known otoliths of T. capelanus of the same size. This is not surprising because otoliths of a species are often more slender towards their northern, colder, limits, as indicated in the section "Factors influencing otolith shape". It is, therefore, most likely that the otolith comes from T. capelanus, but it cannot yet be excluded completely, that it belongs to T. luscus. Hopefully more individuals of T. luscus or T. capelanus will be found on the Faroe Bank in the near future. During the March fish survey of 2015 on the Faroe Bank scientist Peter Steingrund carefully looked for T. luscus among the $355 \mathrm{~kg}$ of A. minutus that were caught, but unfortunately he could not find any specimen of this species (personal communication Eiðfinn Magnussen). Both T. capelanus and T. luscus were not known from the Faroe Bank before (personal communication E. Magnussen). The haul in which this specimen was caught was made between $61^{\circ} 01^{\prime} \mathrm{N} 8^{\circ} 10^{\prime} 05 \mathrm{~W}$ en $61^{\circ} 00^{\prime} 9 \mathrm{~N} 8^{\circ} 16^{\prime} \mathrm{W}$ at depths between 120 and $114 \mathrm{~m}$ on 15 September 2003. The fish was a one-year-old male (TL $181 \mathrm{~mm}$, FW (total fish weight in g) $55 \mathrm{~g}$, OL $8.4 \mathrm{~mm}$ ). It is very remarkable that this southern species has been found so far north. This very northern occurrence probably is quite recent and must be attributed to the global warming. In the warmer Miocene and Pliocene epochs T. capelanus was very common in the North Sea.

Allotrisopterus minutus (Figure 13). This species is known to occur abundantly from the Vikna Islands, Norway $\left(65^{\circ} \mathrm{N}\right)$ to the Skagerrak, nearly the whole North Sea, around the Faroe Islands, on Rockall Bank, around Great Britain and Ireland, in the English Channel and in the Atlantic up to 
and including at least the northern part of Portugal [77]. The most northern occurrence known from the literature is at Saltfjorden near Bodö, Norway $67^{\circ} 15^{\prime} \mathrm{N}$ [78].

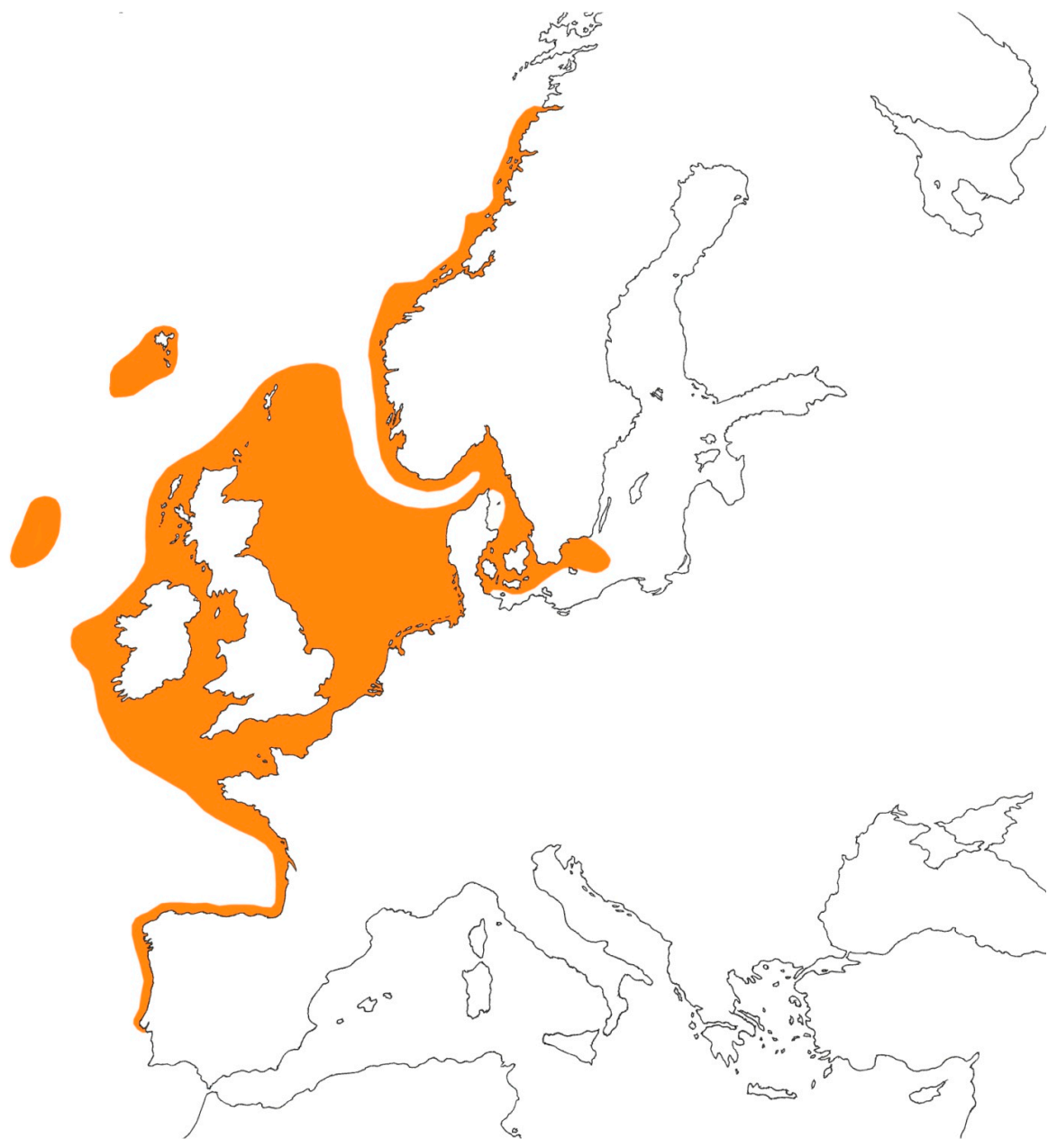

Figure 13. Present geographic distribution of Allotrisopterus minutus.

Less numerous it is in the Kattegat, the southern part of the Baltic Sea, and between the Faroe Islands and Iceland. The southernmost limit along the Portuguese coast is not exactly known, because in distribution maps $A$. minutus is taken together with T. capelanus, which latter species mostly is taken erroneously as a subspecies of $A$. minutus. However, from the data presented in Gomes et al. [79] it is clear that T. luscus and A. minutus are abundant up to the Tagus estuary $\left(38^{\circ} 40^{\prime} \mathrm{N}\right)$ and are more rare south of it. From this it can be concluded that the southernmost limit of A. minutus will be at least at the Tagus estuary, but may be even more to the south.

Neocolliolus esmarkii (Figure 14). This species has the most northerly distribution of all four recent species. It is abundant from about $71^{\circ} \mathrm{N}$ off northern Norway to the Skagerrak, in the deeper, northern part of the North Sea, around Scotland, Ireland and the western part of England and Wales up to the northern part of Brittany and the western part of the English Channel, and also south and west of Iceland, at Rockall Bank, and south of the Faroe Islands. Less common is this species along the whole northern coast of Norway in the south-western part of the Barents Sea to off the southwestern part of Novaya Zemlya, south and southwest of Svalbard up to $80^{\circ} \mathrm{N}$, in the Kattegat, around the Faroe Islands, north and east of Iceland, around Jan Mayen Island and Bear Island, central east of Greenland, and in the central and eastern part of the English Channel [80,81]. The southernmost part of its certain distribution is off the Gironde estuary, France, in the Bay of Biscay at $45^{\circ} 40^{\prime} \mathrm{N}$ [82]. 


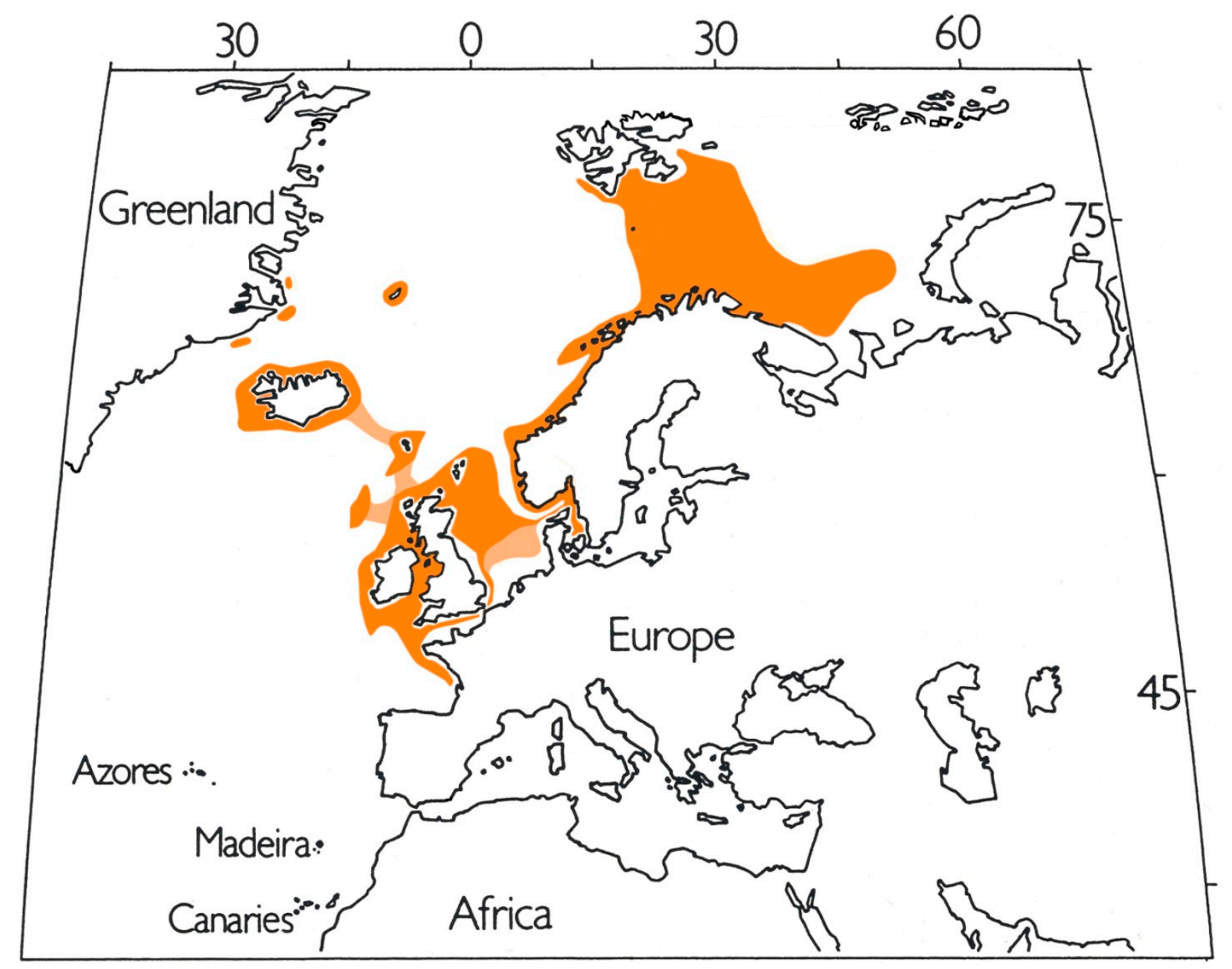

Figure 14. Present geographic distribution of Neocolliolus esmarkii. Lighter orange in the North Sea means lesser abundance. Lighter orange in the Atlantic Ocean means probable connection with more westerly occurrences.

Interestingly, I have identified one broken, juvenile otolith of this species among a larger number of otoliths of various species of myctophids from a sediment sample from the present sea floor of the Atlantic Ocean off southern Morocco $\left(28^{\circ} 56^{\prime} 57^{\prime \prime} \mathrm{N}, 12^{\circ} 30^{\prime} 56^{\prime \prime} \mathrm{W}\right.$, depth $524 \mathrm{~m}$, collection P. Gaemers, from W. Sparreboom, The Netherlands) (Figure 12(2a,b)). This location is at the same latitude as the island Lanzarote (Canary Islands). The peculiar and unique shape of the collum of this otolith shows that it belongs to N. esmarkii. (The accompanying otolith fauna consists of the following species: Benthosema glaciale, Ceratoscopelus maderensis, Diaphus sp. 1, D. sp. 2, Hygophum macrochir, Myctophum punctatum, Notoscopelus sp., Myctophidae indet. The geological age of this N. esmarkii otolith most likely is Weichselian (last glacial), because the southernmost occurrence of this species at present is the Atlantic in southern France [16], a long distance to the north and west from this location.

\subsection{Evolution of Trisopterines}

A large amount of new data is available on trisopterine fossil otoliths compared with my first paper on the evolution of cod otoliths in 1976 [3]. For a large part this material is still unpublished, thus a lot of data in this section are still provisionally presented and will be the subject of a paleontological paper in which the new taxa will be described. The new data show that the evolution of trisopterines is much more complex, comprising more lineages and much shorter lengths of lineages than earlier thought. This justifies the establishment of extinct fossil genera. During his whole career up to now Nolf did not want to recognize fossil genera based on otoliths only (see for instance [4] and [83]) 
and he refused to use such available genus names even when he must admit that he could not fit certain fossil otoliths in a recent genus, like Ensigadus ensiformis (Steurbaut and Herman, 1978) that is named "Gadida" ensiformis in Nolf [83] and "genus Gadidarum" ensiformis in earlier publications for example in Nolf and Steurbaut [4]. Moreover, describing new fossil species based on otoliths with the provisional genus names "genus Gadidarum" or "Gadida", is not allowed by the International Code for Zoological Nomenclature.

The study of fossil and recent Gadidae otoliths makes it possible to reconstruct many evolutionary lineages, of which many appear to be extinct. This knowledge of the Gadidae evolution can be used successfully for establishing many biozones by which the relative geological age of the sediments in which the otoliths are found, can be accurately determined [24,84-87]. With the many new data it will be possible to extend this biozonation considerably.

The earliest representatives of the trisopterines are known from the Early Oligocene (Rupelian), about 34 million years ago. Only one evolutionary stage, probably the last stage, is known from the oldest, still unnamed lineage (Figure $15(1 \mathrm{a}-\mathrm{c}, 2 \mathrm{a}-\mathrm{c})$ ). The origin of this lineage must lie in the Late or Middle Eocene, but temperatures were too high for the Gadidae in the North Sea Basin before the Oligocene, so they must have lived more to the north from where no data are yet available. The small, thick and high otoliths show sexual dimorphism, and must belong to adult fishes. The pseudocolliculum is well developed and nearly completely fills the column. From this lineage the extinct genus Semeniolum originates by cladogenesis (Figure 15(3a-c,4a,b)), a lineage that is known from the base of the Early Oligocene (Rupelian, c. 34 million years ago) to the lower part of the Late Oligocene (Chattian A). Members of this lineage always have a pseudocolliculum in juvenile otoliths, but this feature is absent in adult ones. The otoliths become larger and somewhat more slender than those of the former lineage. The lineage succeeding Semeniolum is still unnamed and is only known from the Late Oligocene (Chattian, 28.5-23 million years ago). These otoliths again become larger and can be more slender than the ancestral lineage, and are strikingly thick. They show sexual dimorphism and do not have a pseudocolliculum (Figure 15(5a,b,6a,b). Another lineage with much thinner and again larger otoliths is also known from the base of the Late Oligocene, resembling the genus Trisopterus in many respects (Figure $15(7 \mathrm{a}-\mathrm{c})$ ). Its origin may be connected with the former one, but could also directly be connected with the Semeniolum lineage by cladogenesis. The main differences with Trisopterus are, that the otoliths are less bent lengthwise, flatter and smaller. A pseudocolliculum is absent in this lineage. Undoubtedly this lineage is the forerunner lineage of Trisopterus, but it is still unknown from the Early Miocene. 

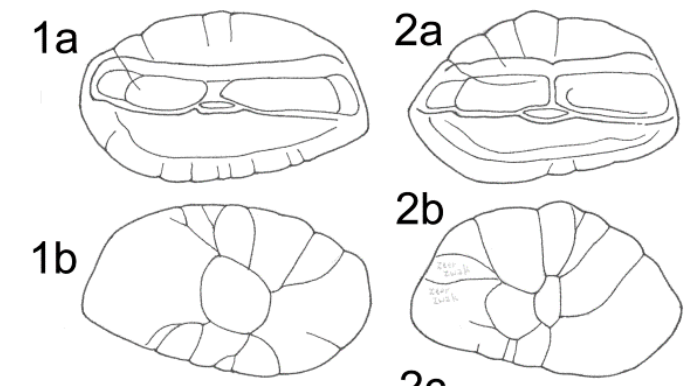

2c
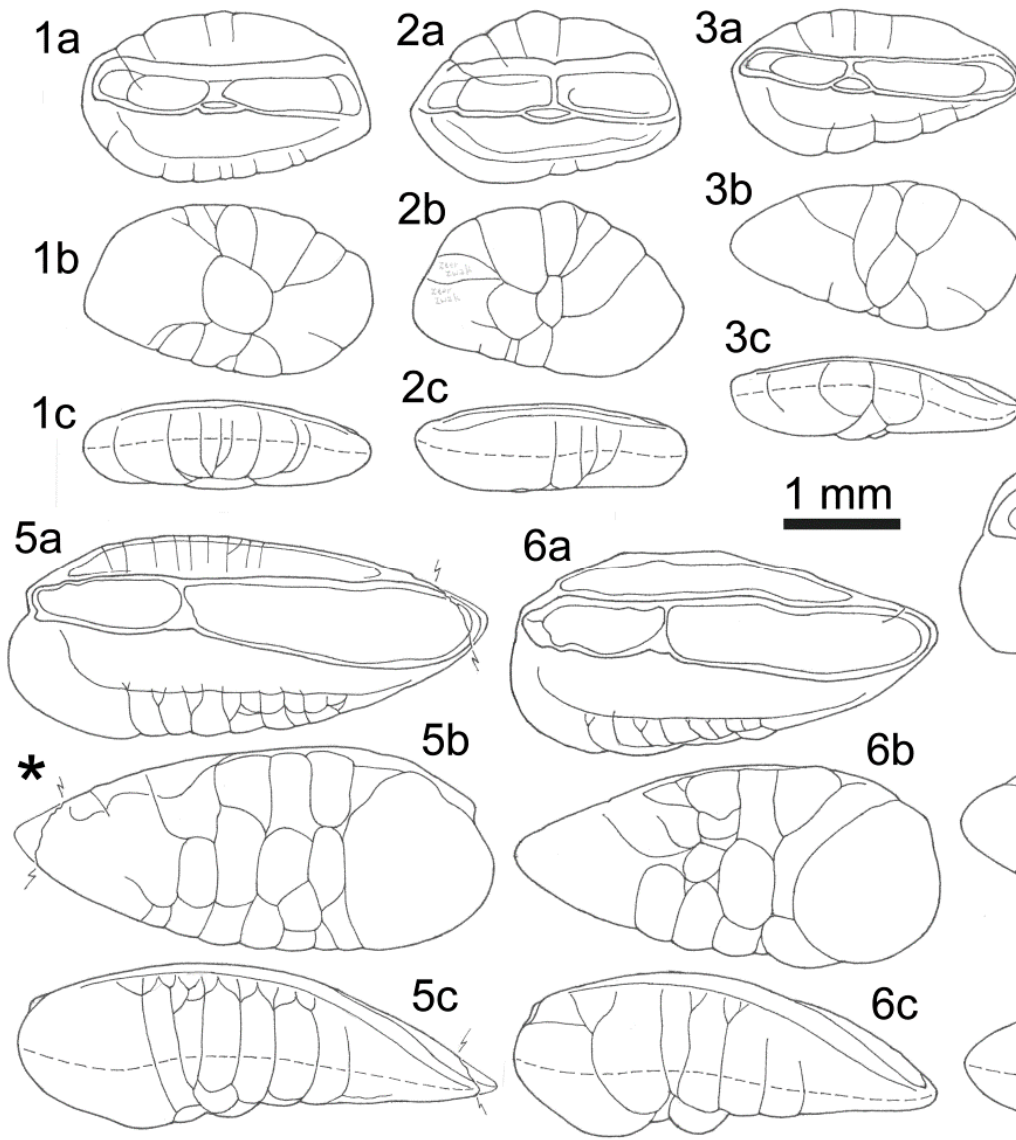

$3 b$

3c
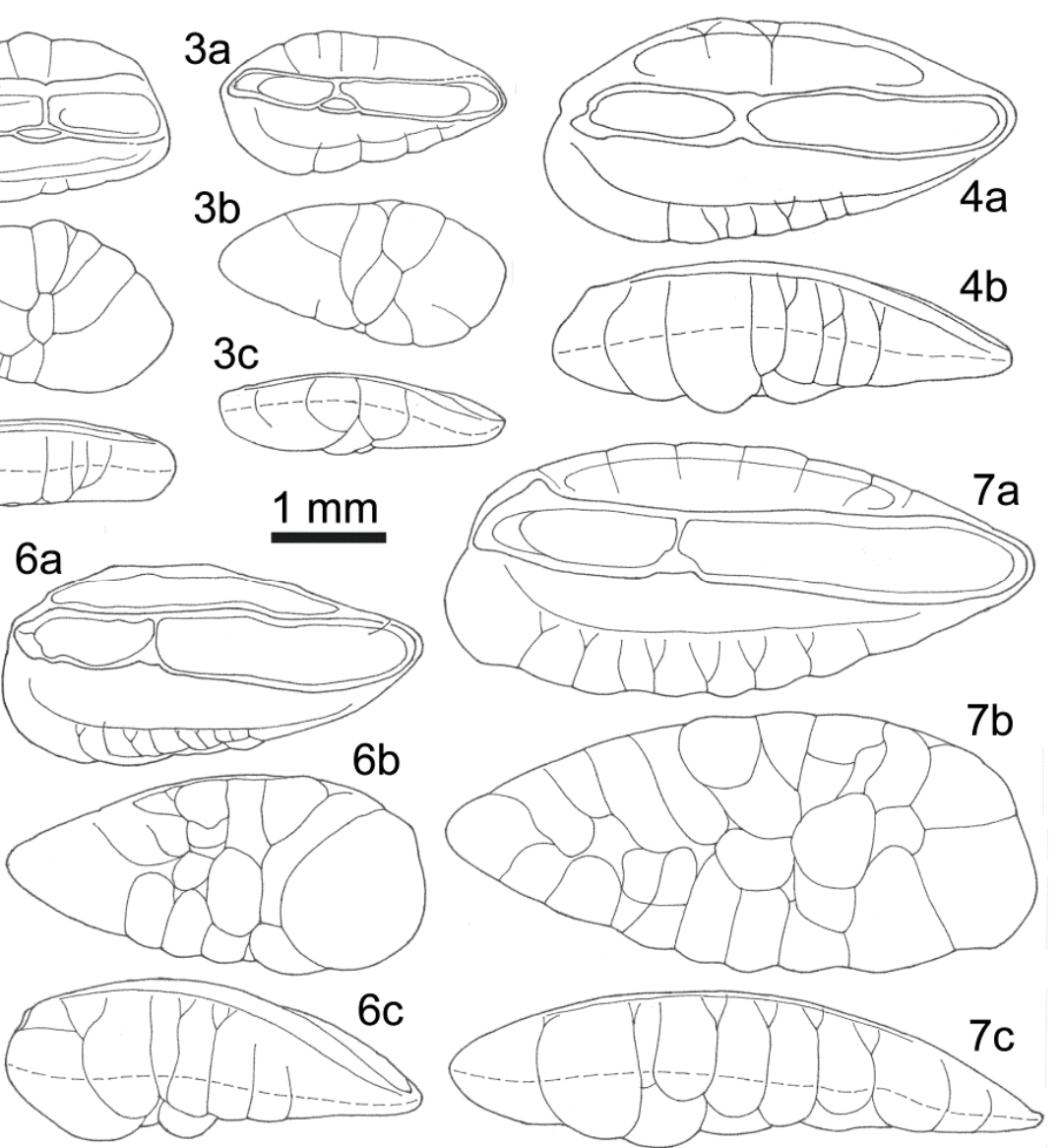

Figure 15. Examples of earlier evolution of trisopterines. (1a-c,2a-c) + Trisopterini, new genus and species 1, Early Oligocene, Rupelian, Kotten Member, borehole Tervoert, Winterswijk, The Netherlands; (1a-c) female, bed 28, 23.8-24.25 m below surface; (2a-c) male, bed 29-base bed 30, 22.3-22.8 m below surface; (3a-c) + Semeniolum rupelense Gaemers, 1984, Early Oligocene, Rupelian, Kotten Member, borehole Tervoert, Winterswijk, The Netherlands, top bed 23-base bed 24, 26.7-27.2 m below surface. $(\mathbf{4 a}, \mathbf{b})+$ Semeniolum rupelense Gaemers, 1984, Late Oligocene, base of Chattian A, Söllingen, Germany. $(\mathbf{5 a}-\mathbf{c}, \mathbf{6 a}-\mathbf{c})+$ Trisopterini, new genus and species 2, Late Oligocene, Chattian A, (5a-c) female, mirror images, indicated with *, (6a-c) male; $(\mathbf{7 a - c})+$ "Trisopterus" kasselensis n. ssp., Late Oligocene, base of Chattian A.

Fossil otoliths show that the origin of the closely related T. luscus and T. capelanus lineages both are in the Early Miocene of the Northeast Atlantic and North Sea, at least 18 million years ago (Figure 16(1a-e,2a-c)). These sister species indeed form a monophyletic group, as correctly concluded in [21]. Furthermore, there are two extinct lineages that I provisionally include also in the genus Trisopterus, the Trisopterus spectabilis and Trisopterus arcuatus lineages. Interesting is, that the T. spectabilis lineage goes more rapidly through its evolutionary cycle (Figure 16(4a-d)). It is well represented in the North Sea Basin and became extinct at the end of the Miocene, about 5.5 million years ago. Although it is not yet completely sure, it seems that this lineage started later (c. 15 or 16 million years ago) than those of T. luscus and T. capelanus. Furthermore, T. spectabilis displays a much stronger allometry in the ontogeny of the otoliths. These data suggest that the T. spectabilis lineage very likely is not a sister lineage of the other two. Finally, only one evolutionary stage of T. arcuatus (Radwańska, 1992) has been found in the Middle Miocene (Badenian) of southeastern Poland (Figure 16(3)). This lineage most likely became also extinct in the Late Miocene. The former sea in that area belonged to the Paratethys and — as far as is known—had no direct connection with the North Sea, but only via the 
Mediterranean Sea and the Atlantic Ocean. Precise chronostratigraphic correlation with the North Sea Basin is therefore difficult, indicated with a question mark in Figure 16(3).

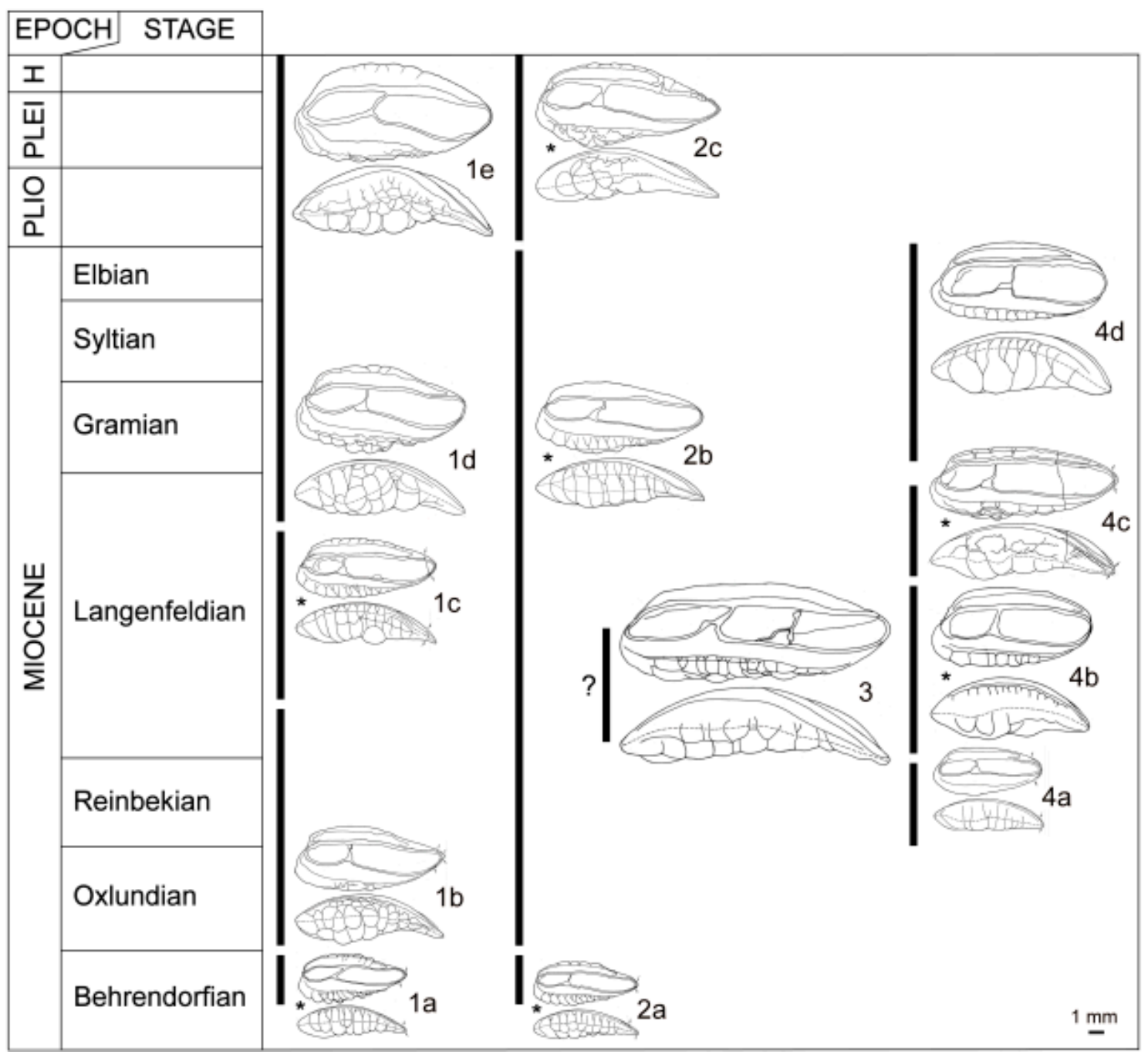

Figure 16. Evolutionary lineages of Trisopterus. Otoliths indicated with an asterisk are mirror images. (1a) T. luscus n. ssp. 1, Behrendorfian, Edegem Sands, bed 6, Slijkhoek, Antwerp, Belgium; (1b) T. luscus concavus (Gaemers, 1976), Oxlundian, Miste Bed, Miste, Winterswijk, The Netherlands. (1c). T. luscus n. ssp. 2, Langenfeldian, borehole Straat, 518.7-520.7 m below surface, near Roermond, The Netherlands; (1d) T. luscus luscus (Linnaeus, 1758), Gramian, borehole Straat, 494.7-495.7 m below surface, near Roermond, The Netherlands; (1e) T. luscus luscus (Linnaeus, 1758), Recent, North Sea, TL 388; (2a) T. capelanus n. ssp. 1, Early Miocene, Behrendorfian, Berchem Formation, Kiel Sands, borehole airfield Haamstede, The Netherlands, 132-133 m below surface; (2b) T. capelanus n. ssp. 2, Gramian, Gram, Denmark; (2c) T. capelanus capelanus (Lacepède, 1800), Recent, Aegean Sea, east of mainland of Greece, 50-100 m depth, female, TL 200; (3) + T. arcuatus (Radwanska, 1992), Badenian, Middle Miocene, Rybnica, Poland; (4a) + T. spectabilis n. ssp. 1, Reinbekian, borehole Straat, 636.5-638.5 m below surface, near Roermond, The Netherlands; (4b) + T. spectabilis spectabilis (Koken, 1891), Langenfeldian, Gross Pampau, Germany; (4c) + T. spectabilis n. ssp. 2, Langenfeldian, borehole Straat, 524.7-526.7 m below surface, near Roermond, The Netherlands; (4d) + T. spectabilis angustus (Gaemers and Schwarzhans, 1982), Syltian, Sylt, Germany.

The origin of the A. minutus lineage probably is in the Middle Miocene, c. 15 million years ago (Figure $17(1 \mathrm{a}-\mathrm{c})$ ). The oldest known representatives of the $N$. esmarkii lineage are from the Early Pliocene, c. 5 million years ago (Figure $17(3 a-c)$ ), but its still unknown origin must be in the 
Late Miocene (probably a few million years earlier). Its forerunner lineage, "Neocolliolus" vikingensis (Gaemers, 1987) is partly known and ranges at least between c. 8 and 11 million years (Late Miocene) (Figure 17(2a-c)). From this it can be concluded that a direct common ancestor with the A. minutus lineage does not exist. The Neocolliolus lineage and its forerunner lineage both evolved more rapidly than the other trisopterine lineages.

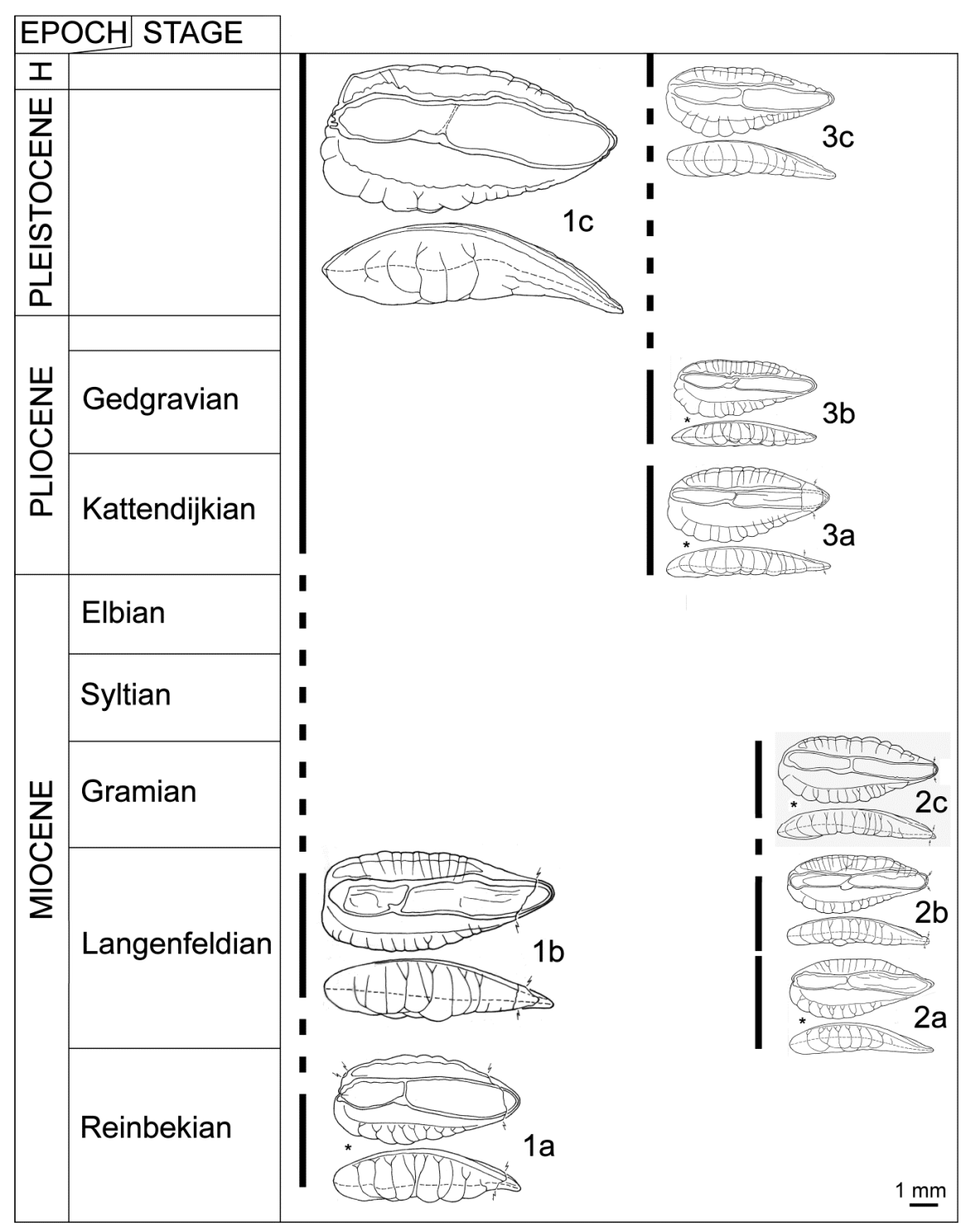

Figure 17. Evolutionary lineages of Allotrisopterus and Neocolliolus sensu lato. Otoliths indicated with an asterisk are mirror images. (1a) Allotrisopterus minutus n. ssp.1, Reinbekian, borehole Straat, 650.2-652.2 m below surface, near Roermond, The Netherlands; (1b) A. minutus incognitus (Gaemers, 1976), Langenfeldian, Hohen Woos, Germany; (1c) A. minutus minutus (Linnaeus, 1758), Recent, Faroe Bank, Faroe Islands, cruise 03680025, number 5091, female, TL 256, TW 155, OL 10.57; (2a) † "Neocolliolus" vikingensis n. ssp. 1, Langenfeldian, borehole Straat, 488.7-489.7 m below surface, near Roermond, The Netherlands; $(\mathbf{2} \mathbf{b})+$ "N." vikingensis n. ssp. 2, Gramian, borehole Straat, 430.5-431.5 m below surface, near Roermond, The Netherlands; (2c) † "N." vikingensis vikingensis Gaemers, 1987, Gramian, borehole J, Viking Graben, northern North Sea; (3a) Neocolliolus esmarkii pliocenicus (Gaemers and Schwarzhans, 1973), Kattendijkian, Early Pliocene, Kerkstraat, Antwerp, Belgium (3b) N. esmarkii n. ssp., Middle/Late Pliocene, Mill-Langenboom, The Netherlands; (3c) N. esmarkii esmarkii (Nilsson, 1855), Recent, North Sea, TL 140, OL 5.90. 
It is striking that the Oligocene lineages have shorter evolutionary cycles than most younger ones. As a consequence the Oligocene lineages succeed one another more rapidly than the younger ones.

\section{Discussion and Conclusions}

As shown in this paper, fossil and recent otoliths are indispensable for a better understanding of the evolution, mutual relationships, systematics and geographic distribution of closely related species. If only data from recent species are available-even if they come from various sources (such as external features, meristics, otoliths and genetics) and have been elaborated with sophisticated mathematical methods-it may remain difficult to assign a species to the right genus and is it often hazardous to reconstruct the phylogeny and the biogeographic history. Cladistics, also called "phylogenetic systematics", introduced by Willy Hennig [88], originally is solely based upon recent species and their various characteristics, and is at best a serious attempt to a phylogenetic reconstruction. Cladograms constructed by this method are not evolutionary, phylogenetic trees because they do not show how ancestors are related to descendants. However, there are a lot of scientists who consider cladograms as a kind of phylogenetic trees. Without inclusion of fossil representatives a certain and reliable phylogeny can never be obtained with this method, even when genetic data are included. Fossil data are difficult to integrate in the cladistic system of Hennig, because time-and consequently also stratigraphic data-is not easy to fit into this system [89]. The uncertainty about phylogeny by means of cladistics can also be demonstrated by the proposal of several possible cladograms in many publications using cladistics, without having the ability to choose the right one. The term "phylogenetic systematics" for Hennig's method therefore is misleading and should be avoided if only recent species are involved, what is usually the case. Hennig's method should therefore only be called "cladistics", because this term does not cause confusion.

The much-used concept of vicariance in Hennig's method, for instance, is often not provable without fossils. A good definition of vicariance is: the geographical separation and isolation of two subpopulations of a species by some sort of barrier, resulting in two different populations leading to separate varieties and, in the end, to different species. This is a type of allopatric speciation inferred from Darwin's theory of evolution. Two related species in the same genus that nowadays live in two separate areas are therefore often called vicariant species. However, the present geographic distribution of two species in separate areas is not always guarantee that geographical separation and isolation is the original process of the speciation. In the past the geographical distribution of such species might have been very different. A good example is found in the species T. capelanus and A. minutus that were supposed to be subspecies of one species. The latter species is only living in the Atlantic, including the North Sea and Norwegian Sea. T. capelanus was thought to be living nowadays only as an endemic in the Mediterranean Sea. These species were seen as vicariant species for a long time. As demonstrated in this publication, fossil and recent otoliths, and also genetics, have shown convincingly that these species are not even sister species.

Gonzalez et al. [22] hypothesize that the most recent common ancestor of the real sister species T. luscus and T. capelanus had a large geographic distribution including the Atlantic as well as the Mediterranean. The time of origin of these species from a common ancestor at about 19.7 or 21 million years that these authors have calculated is a good estimate as the fossil otoliths show, but the final closure of the Tethys Ocean blocking the connection between the Mediterranean and the Indian Ocean around that time has nothing to do with the speciation of Trisopterus, because the oldest known ancestors in the T. luscus and T. capelanus lineages occur in the same Early Miocene deposits of the North Sea Basin and not in the Mediterranean. Thus, fossil otoliths of these lineages indicate that both originated in the northeastern Atlantic including the North Sea. There was, and still is, no barrier in that area, thus these species are an example of sympatric speciation. There is much evidence that T. luscus and T. capelanus lived together in the same area and are distinguishable by means of their otoliths during their whole known, long geological history, and there is no reason to suppose that it was different during a possible unknown part of their phylogeny $[55,84,90-92]$ (see also Figure 16). 
The Messinian salinity crisis ( 6.0 to 5.3 mya) might have caused disappearance of many marine species from the Mediterranean including T. capelanus, as Gonzalez et al. [22] assume, but the only area where the T. capelanus lineage could have survived during that time was in the Atlantic where the separate T. luscus lineage continually was living. A post-glacial, very recent invasion of $T$. capelanus in the Mediterranean as considered by Tirard et al. [93] who synonymize this species with T. luscus, is certainly not realistic, because conditions for this species in the Mediterranean during the Pliocene and Pleistocene were good enough to live there in these periods.

N. esmarkii is the most aberrant species within the trisopterines. Many characteristics of the fishes themselves, their otoliths, their habitat and food justify its taxonomic position in the separate genus Neocolliolus.

Closer relationships between A. minutus and N. esmarkii, compared with the other trisopterines, are demonstrated by otolith characteristics and genetics. The greater taxonomic distance of $A$. minutus and N. esmarkii to T. luscus and T. capelanus is based upon various characteristics of the fishes, such as otolith morphology and genetic data $[18,22]$, and also upon phylogenetic data inferable from fossil otoliths. These data together do not allow including A. minutus in the genus Trisopterus or Neocolliolus. All available data in combination justify the erection of the new genus Allotrisopterus for T. minutus. The similarities in fish shape and size of T. capelanus and A. minutus are therefore due to convergence, and not to close relationship.

The fossil otoliths demonstrate clearly that the trisopterines do not directly form a monophyletic group as assumed by most ichthyologists up to now, including Delling et al. [21]. The only real sister group relationship exists between T. luscus and T. capelanus, and therefore the genus name Trisopterus should be restricted to these taxa alone. Their common ancestry lies in the Early Miocene. The most recent common ancestor of the four recent trisopterines together is not yet known, but must have lived farther back in time, in the older part of the Late Oligocene or perhaps even in the younger part of the Early Oligocene.

The tribe Trisopterini introduced by Endo [5] must be redefined. Apart from fossil genera this tribe only contains the recent genera Trisopterus, Allotrisopterus and Neocolliolus. Micromesistius, Boreogadus and Arctogadus must be excluded from this tribe. Although the genus Micromesistius is not so distant from the trisopterines [21], it is more closely related to Gadiculus [7,94], and might be included in the tribe Gadiculini. The genus Boreogadus belongs to the tribe Gadini based on morphology and genetic data [7], and according to morphological characteristics Arctogadus should also be placed in the Gadini.

\section{Materials and Methods}

\subsection{Recent Otoliths}

During a fish survey of the Rijksinstituut voor Visserijonderzoek (RIVO, IJmuiden, The Netherlands, now part of Wageningen IMARES, Institute for Marine Resources \& Ecosystem Studies) in the North Sea, I collected the first otoliths of the three trisopterine species occurring in the North Sea in February 1969. I obtained many hundreds of recent otoliths of Trisopterus luscus (Linnaeus, 1758) by buying the fishes on the fish market in Leiden (The Netherlands) for our own consumption in the course of tens of years. I could study hundreds of otoliths of the three North Sea trisopterine species from the collection of Maarten Frederik (Mardik) Leopold (Texel, The Netherlands) from the North Sea. A series of otoliths of 194 recent fishes identified as Trisopterus capelanus appeared to include otoliths of 15 fishes of T. luscus off the eastern coast of Greece, and were kindly sent and given to me by Chrissy-Yanna Politou (Hellinikon, Greece). I could also study a large collection of recent otoliths of 265 fishes identified as Trisopterus minutus (Linnaeus, 1758) from the Faroe Bank around the Faroe Islands, that was used in the BSc Thesis of Marita Magnussen and kindly loaned to me by her supervisor Eyðfinn Magnussen (Torshavn, Faroe Islands). Two fishes of this collection appeared to belong to Neocolliolus esmarkii and one most likely to Trisopterus capelanus. On holiday trips and excursions in Spain, Portugal, Greece, France and Morocco I bought trisopterine fishes on fish markets and dissected 
the otoliths. Gerhard C. Cadee (Texel, The Netherlands) found otoliths in bottom samples in and off the Ría de Arosa (Galicia, northwestern Spain) most of which belong to Recent and Holocene trisopterine species, collection Oertijdmuseum De Groene Poort (Museum Ammonietenhoeve Boxtel), Boxtel, Noord-Brabant, The Netherlands (collection numbers MAB 001307-001342). Smaller numbers of recent trisopterine otoliths were obtained from some other collectors. William N. Eschmeyer (California Academy of Sciences, San Francisco, CA, USA.) allowed me to dissect the otoliths from some trisopterines (otoliths now in author's collection): 1 specimen, T. luscus (identified as Brachygadus minutus) from Venice (Italy), California Academy of Sciences no. 47126; 1 specimen, T. luscus from Palermo (Italy), California Academy of Sciences no. 47124; 1 specimen, T. capelanus from Naples (Italy), California Academy of Sciences no. 20894; 2 specimens, T. capelanus from Naples (Italy), Stanford University Natural History Museum no. 2461.

\subsection{Fossil Otoliths}

Many species and phylogenetic stages of fossil Gadidae otoliths are known in the literature from the North Sea Basin and the northeastern Atlantic from The Netherlands, Belgium, Germany, Denmark, England, France, Poland and the British part of the North Sea. There are also many trisopterine otoliths available that are still unpublished. I hope to publish this material in one or more other papers that are in preparation, because it is beyond the scope of this paper. A lot of important new otoliths of trisopterine Gadidae occurred in borehole Straat (numbered 58G-191 by the Geological Survey of The Netherlands, now part of TNO-NITG), in the middle of the province of Limburg, close to the city of Roermond, in The Netherlands. I collected large samples of the thick Miocene sequence in this borehole myself and I washed the large samples. The picking of the otoliths was done by Messrs André J. J. Jansen and Cor Karnekamp.

\subsection{Picturing and Measuring}

I have drawn the otoliths at magnifications of $15 \times(12 \times 1.25)$ and $31.25 \times(25 \times 1.25)$ under a Wild M5 binocular microscope with a drawing tube. The otoliths were measured with a sliding calliper with an accuracy of $0.05 \mathrm{~mm}$; with a ten times magnifying achromatic hand-lens the measurements were estimated to a hundredth of an $\mathrm{mm}$ on the sliding calliper. Photographs were taken by the author at the Center of Biodiversity Naturalis The Netherlands, Leiden, using a digital multifocal camera (Leica MZ16A, Leica Microsystems, Wetzlar, Germany) with accompanying software coupled to a personal computer. All drawings of otoliths have been pictured as right sagittae in order to provide the easiest mutual comparison; thus all otoliths presented as mirror images are left sagittae, indicated by an asterisc.

\subsection{Taxon Validation}

The new taxon Allotrisopterus was registered in ZooBank in 2017 (urn:lsid:zoobank.org:pub:

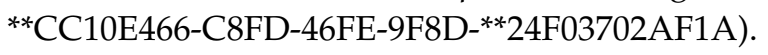

Acknowledgments: I am thankful to Mardik F. Leopold (NIOZ Royal The Netherlands Institute for Sea Research, Texel, The Netherlands) and Eiðfinn Magnussen (University of the Faroe Island, Torshavn) for the loan of large numbers of trisopterine otoliths. I am grateful to Gerhard C. Cadeé (NIOZ Royal Netherlands Institute for Sea Research, Texel, The Netherlands) and Chrissi-Yianna Politou (National Centre of Marine Research in Hellinikon, Greece) for the otoliths they gave me, as well as the late Juan Bauza-Rullan (Palma de Mallorca, Spain), William N. Eschmeyer (Institute of Biodiversity Science and Sustainability, California Academy of Sciences, San Francisco, CA, USA). Dirk Nolf (Royal Belgian Institute of Natural Sciences, Brussels, Belgium), I. Óskarsson, (Marine Research Institute, Reykjavík, Iceland) and Jouke van der Zee (Nijmegen, The Netherlands) for providing me with smaller numbers of otoliths. I thank Antoni Lombarte (Institut de Ciènces del Mar-CSIC, Barcelona, Spain) for measurements of a small series of Trisopterus otoliths. I thank André F.J. Jansen (Bovenkarspel, The Netherlands) and Cor Karnekamp (Diemen, The Netherlands) for picking the otoliths and other fish remains from the residues of borehole Straat near Roermond, The Netherlands). I thank Lars van den Hoek Ostende (Center of Biodiversity Naturalis Netherlands, Leiden) for access to the photographic equipment and Jaap J. Oppedijk (Leiden, The Netherlands) for assembling and digitalizing the figures and plates. No funding or grants were 
received for this study. Finally, I thank the two anonymous reviewers for their comments by which the text could be improved.

Conflicts of Interest: The author declares no conflict of interest.

\section{Abbreviations}

The following abbreviations are used in this publication:

TL Total fish length in $\mathrm{mm}$

FW Total fish weight in $\mathrm{g}$

OL Otolith length in $\mathrm{mm}$

$\mathrm{OH}$ Otolith height (width) in $\mathrm{mm}$

OT Otolith thickness in $\mathrm{mm}$

\section{References}

1. Svetovidov, A.N. Fauna SSSR: Ryby, (n.s. 34), Vol. 9, Fasc. 4; Treskoobraznye [Gadiformes]: Zoologicheskii Institut Akademi Nauk SSSR, Moscow-Leningrad, Russia, 1948; p. 294.

2. Svetovidov, A.N. Fauna of the U.S.S.R., Fishes, Gadiformes; Zoologicheskii Institut, Akademii Nauk SSSR, Published by Israel Program for Scientific Translations: Jerusalem, Israel, 1962; Volume 9, vip. 304p.

3. Gaemers, P.A.M. New concepts in the evolution of the Gadidae (Vertebrata, Pisces), based on their otoliths. Meded. Werkgr. Tert. Kwart. Geol. 1976, 13, 3-32.

4. Nolf, D.; Steurbaut, E. Importance and restrictions of the otolith-based fossil record of gadiform and ophidiiform fishes. In Papers on the Systematics of Gadiform Fishes; Cohen, D.M., Ed.; Science Series; Natural History Museum of the Los Angeles County: Los Angeles, CA, USA, 1989; Volume 32, pp. 47-58.

5. Endo, H. Phylogeny of the order Gadiformes (Teleostei, Paracanthopterygii). Mem. Grad. School Fish. Sci. Hokkaido Univ. 2002, 49, 75-149.

6. Nelson, J.S. Fishes of the World, 4th ed.; John Wiley and Sons: Hoboken, NJ, USA, 2006; p. 624.

7. Teletchea, F.; Laudet, V.; Hänni, C. Phylogeny of the Gadidae (sensu Svetovidov, 1948) based on their morphology and two mitochondrial genes. Mol. Phylogen. Evol. 2006, 38, 189-199. [CrossRef] [PubMed]

8. Roa-Varón, A.; Ortí, G. Phylogenetic relationship among families of Gadiformes (Teleostei, Paracanthopterygii) based on nuclear and mitochondrial data. Mol. Phylogen. Evol. 2009, 52, 688-704. [CrossRef] [PubMed]

9. Howes, G.J. Anatomy of the Melanonidae (Teleostei: Gadiformes), with comments on its phylogenetic relationships. Bull. Nat. Hist. Mus. (Zool.) 1993, 59, 11-31.

10. Fahay, M.P. Early Stages of Fishes in the Western North Atlantic Ocean (Davis Strait, Southern Greenland and Flemish Cap to Cape Hatteras). Volume 1. Acipenseriformes through Syngnathiformes; NW Atl. Fish. Org.: Dartmouth, NS, Canada, 2007; p. 931.

11. Eschmeyer, W.N., Ed.; Catalog of Fishes. Updated Internet Version of 31 October 2014. Catalog Databases of CAS Cited in FishBase. Available online: http://researcharchive.calacademy.org/research/ichthyology/ catalog/fishcatmain.asp (accessed on 11 December 2014).

12. Gill, T.P. On the Family Ranicipitidae. Proceedings of the United States National Museum; U.S. Government Printing Office: Washington, DC, USA, 1890; Volume 13, pp. 1-4.

13. Jordan, A.D.; Møller, P.R.; Nielsen, J.G. Revision of the Arctic cod genus Arctogadus. J. Fish Biol. 2003, 62, 1339-1352. [CrossRef]

14. Byrkjedal, I.; Rees, D.J.; Christiansen, J.S.; Fevolden, S.-E. The taxonomic status of Theragra finnmarchica Koefoed, 1956 (Teleostei: Gadidae): Perspectives from morphological and molecular data. J. Fish Biol. 2008, 73, 1183-1200. [CrossRef]

15. Svetovidov, A.N. Gadidae. In Check-List of the Fishes of the North-Eastern Atlantic and of the Mediterranean; Hureau, J.-C., Monod, T., Eds.; UNESCO: Paris, France, 1973; Volume 1, pp. 303-320.

16. Svetovidov, A.N. Gadidae. In Fishes of the North-Eastern Atlantic and the Mediterranean; Whitehead, P.J.P., Bauchot, M.-L., Hureau, J.-C., Nielsen, J., Tortonese, E., Eds.; UNESCO: Paris, France, 1986; Volume 2, pp. 680-710.

17. Schmidt, E.J. Gadiculus argenteus and Gadiculus thori. In Mindeskrift $i$ Anledning af Hundredaaret for Japetus Steenstrups Fødsel; En kreds af Naturforskere: Copenhagen, Denmark, 1913; Volume 14, p. 9. 
18. Mattiangeli, V.; Bourke, E.A.; Ryan, A.W.; Mork, J.; Cross, T.F. Allozyme analyses of the genus Trisopterus: Taxonomic status and population structure of the poor cod. J. Fish Biol. 2000, 56, 474-494. [CrossRef]

19. Mattiangeli, V.; Galvin, P.; Ryan, A.W.; Mork, J.; Cross, T.F. VNTR variability in Atlantic poor cod (Trisopterus minutus minutus) throughout its range: Single locus minisatellite data suggest reproductive isolation for the Faroe Bank population. Fish Res. 2002, 58, 185-191. [CrossRef]

20. Mattiangeli, V.; Ryan, A.W.; Galvin, P.; Mork, J.; Cross, T.F. Eastern and western poor cod (Trisopterus minutus capelanus) populations in the Mediterranean Sea: Evidence from allozyme and minisatellites loci. Mar. Ecol. 2003, 24, 247-258. [CrossRef]

21. Delling, B.; Noren, M.; Kullander, S.O.; González, J.A. Taxonomic review of the genus Trisopterus (Teleostei: Gadidae) with recognition of the capelan Trisopterus capelanus as a valid species. J. Fish Biol. 2011, 79, 1236-1260. [CrossRef] [PubMed]

22. Gonzalez, E.G.; Cunha, R.L.; Sevilla, R.G.; Ghanavi, H.R.; Krey, G.; Bautista, J.M. Evolutionary history of the genus Trisopterus. Mol. Phylogenet. Evol. 2012, 62, 1013-1018. [CrossRef] [PubMed]

23. Gaemers, P.A.M.; Crapon de Crapona, M.-D. Sexual dimorphism in otoliths of haplochromines (Pisces, Cichlidae). Ann. Mus. Roy. Afr. Cent. Sci. Zool. 1986, 251, 151-155.

24. Gaemers, P.A.M. The biostratigraphy of the Nieder Ochtenhausen borehole based on Gadidae otoliths and other fish remains, and the establishment of the Elbian, a new stage for the latest Late Miocene of NW Europe. Geol. Jahrb. 2001, 152, 301-339.

25. Härkönen, T. Guide to the Otoliths of the Bony Fishes of the Northeast Atlantic, 1st ed.; Danbiu ApS.: Hellerup, Denmark, 1986; p. 256.

26. Schwarzhans, W. Otolith-morphology and its usage for higher systematical units, with special reference to the Myctophiformes s.l. Meded. Werkgr. Tert. Kwart. Geol. 1978, 15, 167-185.

27. Nolf, D.; Steurbaut, E. Evidence from otoliths for establishing relationships between gadiforms and other groups. In Papers on the Systematics of Gadiform Fishes; Cohen, D.M., Ed.; Science Series; Natural History Museum of the Los Angeles County: Los Angeles, CA, USA, 1989; Volume 32, pp. 37-45.

28. Lambert, G.; Nielsen, J.R.; Larsen, L.I.; Sparholt, H. Maturity and growth population dynamics of Norway pout (Trisopterus esmarkii) in the North Sea, Skagerrak, and Kattegat. ICES J. Mar. Sci. 2009, 66, 1899-1914. [CrossRef]

29. Lambert, G. Norway pout (Trisopterus esmarkii) life history strategy: Growth and maturity as evidence of possible spawning mortality. In Mémoire de fin d'études Pour l'obtention du Diplôme d'Agronomie Approfondie (DAA) Spécialisation Halieutique; Agrocampus Rennes: Rennes, France, 2007; p. 75.

30. Raitt, D.F.S. Synopsis of the Biological Data on the Norway Pout Trisopterus esmarkii (Nilsson, 1855); FAO Fish Synopsis: Rome, Italy, 1968; Volume 33, pp. 1-36.

31. Saemundsson, B. On the age and growth of the coalfish (Gadus virens L.), the Norway pout (Gadus esmarkii Nilsson) and the poutassou (Gadus poutassou Risso) in Icelandic waters. Meddel. Komm. Danm. Fisk. Havunders. 1929, 8, 1-37.

32. Baranenkova, A.S.; Khokhlina, N.S. Distribution of eggs, larvae and adults of the Norway pout off northwestern Norway and in the Barents Sea. Rap. Proc.-Verb. Réun. Cons. Internatl. Explor. Mer 1968, 158, 90-100.

33. Magnussen, E.; Magnussen, M.D. Ecology of poor-cod (Trisopterus minutus) on the Faroe Bank. Mar. Biol. Res. 2009, 5, 133-142. [CrossRef]

34. Cooper, A. The reproductive biology of poor cod, Trisopterus minutus L., whiting, Merlangius merlangus L., and Norway pout, Trisopterus esmarkii Nilsson, off the west coast of Scotland. J. Fish Biol. 1983, 22, 317-334. [CrossRef]

35. Merayo, C.R. Reproduction and fecundity of the bib Trisopterus luscus (Linnaeus, 1758) (Pisces, Gadidae) in the central region of the Cantabrian Sea (northern Spain). Bol. Inst. Esp. Oceanogr. 1996, 12, 17-29.

36. Labarta, U.; Ferreiro, M.J. Age and Growth of the Galician Coast Pouting (Trisopterus luscus L.) Preliminary Data; CM1982/g:65; ICES: Copenhagen, Denmark, 1982.

37. Alonso-Fernández, A.; Domínguez-Petit, R.; Bao, M.; Rivas, C.; Saborido-Rey, F. Spawning pattern and reproductive strategy of female pouting Trisopterus luscus (Gadidae) on the Galician shelf of north-western Spain. Aquat. Living Resour. 2008, 21, 383-393. [CrossRef] 
38. Recordlijst zeevissen Nederland per 1 Januari 2013 (Nederland. Continentaal Plat). [Record List of Sea Fishes Netherlands at 1 January 2013, Continental Shelf of The Netherlands]. Available online: http://www.ncrz.nl/pdf/NCRZ_lijst_NL.pdf (accessed on 11 December 2014).

39. Ragonese, S.; Bianchini, M.L. Growth, Mortality and Yield-per-Recruit of the Poor Cod Trisopterus minutus Capelanus, from the Strait of Sicily; Naga, Iclarm Quarterly Fishbyte Section: Penang, Malaysia, 1998; pp. 61-70.

40. Šantić, M.; Pallaoro, A.; Mikulandra, I.; Rađa, B.; Jardas, I. Age, growth and mortality of poor cod (Trisopterus minutus L.) from the eastern Adriatic Sea. Arch. Biol. Sci. 2015, 11. [CrossRef]

41. Metin, G.; Ilkyaz, A.T.; Kınacigil, H.T. Growth, mortality, and reproduction of poor cod (Trisopterus minutus Linn., 1758) in the Central Aegean Sea. Turk. J. Zool. 2008, 32, 43-51.

42. Biagi, F.; de Ranieri, S.; Viva, C. Recruitment, length at first maturity and feeding of poor-cod, Trisopterus minutus capelanus, in the northern Tyrrhenian Sea. Ital. J. Zool. 1992, 59, 87-93.

43. Carpenter, K.E.; Stump, E. Trisopterus capelanus. In The IUCN Red List of Threatened Species; Version 2014.3; International Union for Conservation of Nature and Natural Resources: Gland, Switzerland, 2014.

44. Albert, O.T. Biology and ecology of Norway pout (Trisopterus esmarki Nilsson, 1855) in the Norwegian Deep. ICES J. Mar. Sci. 1994, 51, 45-61. [CrossRef]

45. Wheeler, A. Key to the Fishes of Northern Europe; Frederick Warne Ltd.: London, UK, 1978; xixp. 380p.

46. Potter, I.C.; Claridge, P.N.; Warwick, R.M. Consistency of seasonal changes in an estuarine fish assemblage. Mar. Ecol. Progr. Ser. 1986, 32, 217-228. [CrossRef]

47. Albert, O.T. Biology and Ecology of Norway Pout (Trisopterus esmarkii) in the Norwegian Deep; C.M. 1991/G:44; ICES Demersal Fish Comm.: Copenhagen, Denmark, 1991; p. 31.

48. Gibson, R.N.; Robb, L.; Burrows, M.T.; Ansell, A.D. Tidal, diel and longer term changes in the distribution of fishes on a Scottish sandy beach. Mar. Ecol. Progr. Ser. 1996, 130, 1-17. [CrossRef]

49. Cohen, D.M.; Inada, T.; Iwamoto, T.; Scialabba, N. FAO species catalogue. Gadiform fishes of the world (Order Gadiformes). In An Annotated and Illustrated Catalogue of Cods, Hakes, Grenadiers and other Gadiform Fishes Known to Date; FAO Fisheries Synopsis: Rome, Italy, 1990; Volume 125, xp. 442p.

50. Froese, R., Pauly, D., Eds.; FishBase. World Wide Web Electronic Publication, Version 2015. Trisopterus minutus (Linnaeus, 1758), Poor Cod.. Available online: http:/ /www.fishbase.org/summary/481 (accessed on 19 August 2015).

51. Jardas, I. Adriatic Ichthyofauna; Školska knjiga d.d.: Zagreb, Kroatia, 1996; p. 523. (In Croatian)

52. Di Natale, A.; Molinari, A.; Öztúrk, B.; Srour, A. The IUCN Red List of Threatened Species. Trisopterus capelanus. Available online: http://www.iucnredlist.org/details/49911704/0 (accessed on 19 August 2015).

53. Labropoulou, M.; Papaconstantinou, C. Community structure of deep-sea demersal fish in the North Aegean Sea (northeastern Mediterranean). Hydrobiology 2000, 440, 281-296. [CrossRef]

54. Politou, C.-Y.; Papaconstantinou, C. Population biology of Trisopterus minutus capelanus (Gadidae) from the eastern coast of Greece. Cybium 1991, 15, 69-81.

55. Gaemers, P.A.M. New gadiform otoliths from the Tertiary of the North Sea Basin and a revision of some fossil and recent species. Leidse Geol. Meded. 1976, 49, 507-537.

56. Raitt, D.F.S. The Food and Feeding of Gadus Esmarkii (Nilsson) Compared with 0-Group Haddock and Whiting; ICES CM 1961/Gadoid Committee Mar. Res., No. 101; ICES: Copenhagen, Denmark, 1961.

57. Raitt, D.F.S. Observations on the population dynamics of the Norway pout in the North Sea. Rap. Proc. Verb. Cons. Perm. Internatl. Explor. Mer 1968, 158, 85-90.

58. Linnaeus, C. Systema Naturae per Regna Tria Naturae, Secundum Classes, Ordinus, Genera, Species, Cum Characteribus, Differentiis, Synonymis, Locis, 10th ed.; Lars Salvi: Stockholm, Sweden, 1758; Volume 1, p. 824.

59. Artedi, P. Ichthyologia, sive opera omnia de piscibus scilicet: Bibliotheca ichthyologica. Philosophia ichthyologica. Genera Piscium, Synonymia specierum, Descriptiones specierum. Omnia in hoc genere perfectiora, quam antea ulla. Posthuma. In Vindicavit, Recognovit, Coaptavit \& Editit Carolus Linnæus, Med. Doct. E Ac. Imper. N.C.; Conradum Wishoff: Leiden, The Netherlands, 1738; Volume 3, ivp. 88p.

60. Müller, O.F. Zoologiae Danicae Prodromus, seu Animalium Daniae et Norvegiae Indigenarum Characteres, Nomina, et Synonyma Imprimis Popularium; Hallager: Copenhagen, Denmark, 1776; xxxiip. 282p.

61. Lacepède, B. Histoire Naturelle des Poisons; Plassan: Paris, France, 1800; Volume 2, 1xivp. 632p.

62. Rafinesque-Schmaltz, C.S. Précis des Découvertes et Travaux Somiologiques de Mr. C.S. Rafinesque-Schmaltz Entre 1800 et 1814; Ou choix raisonné de ses principales Découvertes en Zoologie et en Botanique pour servir d'introduction à ses ouvrages futurs; Royale Typographie Militaire: Palermo, Italy, 1814; p. 55. 
63. Risso, A. Histoire Naturelle des Principales Productions de l'Europe Méridionale et Particulièrement de Celles des Environs de Nice et des Alpes Maritimes; Levrault: Paris et Strasbourg, Croatia, 1826; Volume 3, xvip. 486p.

64. Schwarzhans, W. The Otoliths from the Miocene of the North Sea Basin; Backhuys Publishers: Leiden, The Netherlands; Margraf Publishers: Weikersheim, Germany, 2010; vp. 352p.

65. Tuset, V.M.; Lombarte, A.; Assis, C.A. Otolith atlas for the western Mediterranean, north and central eastern Atlantic. Sci. Mar. 2008, 72S1, 7-198.

66. Fage, L. Le Capelan de la Méditerranée: Gadus capelanus (Risso) et ses rapports avec les espèces voisines: G. luscus Linné et G. minutus O. Fr. Müller. Arch. Zool. Exp. Génér. Hist. Nat. Morphol. Histol. Évol. Anim. 1911, 6, 257-282.

67. Chaine, J.; Duvergier, J. Distinction des Gadus capelanus, minutus et luscus par leur sagittae. Compt. Rend. Hebdom. Séanc. Acad. Sci. Paris 1927, 184, 977-978.

68. Merayo, C.R.; Villegas, M.L. Age and growth of Trisopterus luscus (Linnaeus, 1758) (Pisces, Gadidae) off the coast of Asturias. Hydrobiologia 1994, 281, 115-122. [CrossRef]

69. Zhang, D.-X.; Smith, J.-A.; Rico, C.; Hewitt, G.M. Isolation and characterization of 10 microsatellite loci in poor cod Trisopterus minutus (L). Mol. Ecol. Notes 2001, 1, 50-52. [CrossRef]

70. Carr, S.M.; Kivlichan, D.S.; Pepin, P.; Crutcher, D.C. Molecular systematics of gadid fishes: Implications for the biogeographic origins of Pacific species. Can. J. Zool. 1999, 7, 19-26. [CrossRef]

71. Cadée, G.C. Molluscan biocoenoses and thanatocoenoses in the Ría de Arosa, Galicia, Spain. Zool. Verhand. Rijksmus. Nat. Hist. Leiden 1968, 95, 1-121.

72. Froese, R., Pauly, D., Eds.; FishBase. World Wide Web Electronic Publication, Version 2015. Trisopterus luscus (Linnaeus, 1758), Pouting. Available online: http://www.fishbase.org/summary/1367 (accessed on 19 August 2015).

73. FAO Aquatic Species Distribution Map of Trisopterus luscus. Available online: http://www.fao.org/fishery/ species/2235/en (accessed on 19 August 2015).

74. Assis, C. Guia para a Identificação de Algumas Famílias de Peixes Ósseos de Portugal Continental, Através da Morfologia dos Seus Otólitos Sagitta; Prémio do Mar Rei D. Carlos, Câmara Municipal de Cascais: Cascais, Portugal, 2004; p. 190.

75. Andrade da Silva, D.M. Discrimination of Trisopterus luscus (Linnaeus 1758) stocks in the northern of Portugal using otolith elemental fingerprints. Master's Thesis, University of Porto, Porto, Portugal, 2010. p. 34.

76. Magnussen, M.D. Ecology of poor cod (Trisopterus minutus) on the Faroe Bank. Bachelor's Thesis, University of the Faroe Islands, Tórshavn, Faroe Islands, 2004. p. 37.

77. Froese, R., Pauly, D., Eds.; FishBase. Computer Generated Map for Trisopterus minutus (Poor Cod). Available online: www.aquamaps.org (accessed on 11 December 2014).

78. Hognestad, P.T.; Vader, W. Saltvannsfiskene i Nord-Norge (The species of marine fishes in North Norway). Tromura 1979, 6, 1-74.

79. Gomes, M.C.; Serrão, E.; de Fátima Borges, M. Spatial patterns of groundfish assemblages on the continental shelf of Portugal. ICES J. Mar. Sci. 2001, 58, 633-647. [CrossRef]

80. Froese, R., Pauly, D., Eds.; FishBase, Computer Generated Map for Trisopterus esmarkii (Norway Pout). Available online: www.aquamaps.org (accessed on 11 December 2014).

81. Mikkelsen, G. Changes in Norway Pout (Trisopterus esmarkii) Abundance and Distribution under Warming Conditions in the Barents Sea. Master's Thesis, University of Bergen, Bergen, Norway, 2014.

82. ICES. Report of the ICES Advisory Committee, 2008. Book 7. Bay of Biscay and Western Iberian Seas; ICES: Copenhagen, Denmark, 2008; p. 122.

83. Nolf, D. The Diversity of Fish Otoliths, Past and Present; Steurbaut, E., Brzobohaty, R., Hoedemakers, K., Eds.; Roy. Belg. Inst. Nat. Sci.: Brussels, Belgium, 2013; p. 222, + 359 plates.

84. Gaemers, P.A.M. A biozonation based on Gadidae otoliths for the northwest European younger Cenozoic, with the description of some new species and genera. Meded. Werkgr. Tert. Kwart. Geol. 1978, 1, 141-161.

85. Gaemers, P.A.M. Otolith biostratigraphy and paleoecology of well Eidelstedt-1, Nordgetränke (Hamburg Area, F.R.G.), and comparison with some other Langenfeldian and Gramian otolith faunas in the North Sea Basin. Meded. Werkgr. Tert. Kwart. Geol. 1978, 2, 95-118. 
86. Gaemers, P.A.M. Otoliths (Gadidae). The description of the interregional zonation (otolith zones) and its stratigraphical consequences. The regional distribution of otolith assemblages; correlation of the interregional zonation with the regional lithostratigraphic formations. In The Northwest European Tertiary Basin. Results of the International Geological Correlation Programme Project No 124; Vinken, R., Ed.; Geol. Jahrb., German Geological Survey BGR: Hannover, Germany, 1988; Volume 100, pp. 369-390.

87. Gaemers, P.A.M. Refined correlations by means of lithostratigraphy and gadid otolith zonation of the Rupelian of the North Sea Basin: A progress report. Bull. Soc. Belge Géol. 1994, 10, 147-157.

88. Hennig, W. Grundzüge einer Theorie der Phylogenetischen Systematik; Deutscher Zentralverlag: Berlin, Germany, 1950; p. 370.

89. Grantham, T. The role of fossils in phylogeny reconstruction: Why is it so difficult to integrate paleobiological and neontological evolutionary biology? Biol. Philos. 2004, 19, 687-720. [CrossRef]

90. Gaemers, P.A.M. A revision of the Gadidae otoliths (Pisces) from the Redonian of the Ligerian Gulf (NW France) and the stratigraphic position of the Redonian. Tert. Res. 1987, 8, 105-125.

91. Lanckneus, J.; Nolf, D. Les otolithes des téléostéens redoniens de Bretagne (Néogène de l'Ouest de la France). Bull. Inst. Géol. Bassin Aquit. 1979, 25, 83-109.

92. Hoedemakers, K. Teleost fish otoliths from the Neogene of Mill-Langenboom (province of Noord-Brabant, The Netherlands. Cainozoic Res. 2013, 10, 35-52.

93. Tirard, C.; Berrebi, P.; Raibaut, A.; Frenaud, F. Parasites as biological markers-Evolutionary relationships in the heterospecific combination of helminths (monogeans) and teleosts (Gadidae). Biol. J. Linn. Soc. 1992, 47, 173-182. [CrossRef]

94. Gaemers, P.A.M.; Poulsen, J.Y. Recognition and distribution of two Gadiculus species, G. argenteus and G. thori, based on otolith morphology, larval pigmentation and molecular evidence. J. Fish Biol. 2016, in press.

(C) 2017 by the author; licensee MDPI, Basel, Switzerland. This article is an open access article distributed under the terms and conditions of the Creative Commons Attribution (CC-BY) license (http://creativecommons.org/licenses/by/4.0/). 